\title{
Immunomodulatory Effects of Kuseonwangdogo-Based Mixed Herbal Formula Extracts on a Cyclophosphamide-Induced Immunosuppression Mouse Model
}

\author{
Joo Wan Kim, ${ }^{1}$ Jae-Suk Choi $\mathbb{D}^{,},{ }^{2}$ Du Jin Seol, ${ }^{1}$ Jai Jun Choung, ${ }^{1}$ and Sae Kwang Ku ${ }^{3}{ }^{3}$ \\ ${ }^{1}$ Aribio Co. Ltd., No. 2-301, Pangyo Seven Venture Valley, 15 Pangyoro 229-gil, Bundang-gu, Sungnam, \\ Gyeonggi-do 13487, Republic of Korea \\ ${ }^{2}$ Division of Bioindustry, College of Medical and Life Sciences, Silla University, 140 Baegyang-daero 700 Beon-gil, \\ Sasang-gu, Busan 46958, Republic of Korea \\ ${ }^{3}$ Department of Anatomy and Histology, College of Korean Medicine, Daegu Haany University, Hanuidae-ro, \\ Gyeongsan-si, Gyeongsangbuk-do 38610, Republic of Korea \\ Correspondence should be addressed to Sae Kwang Ku; gucci200@hanmail.net
}

Received 30 October 2017; Accepted 27 February 2018; Published 8 April 2018

Academic Editor: Raffaele Capasso

Copyright ( 2018 Joo Wan Kim et al. This is an open access article distributed under the Creative Commons Attribution License, which permits unrestricted use, distribution, and reproduction in any medium, provided the original work is properly cited.

\begin{abstract}
Aim. Kuseonwangdogo is a traditional Korean immunomodulatory polyherbal prescription. However, there are no systemic findings on its complex immunomodulatory effects on in vivo models. In this study, we observed the immunomodulatory effects of Kuseonwangdogo-based mixed herbal formula aqueous extracts (MHFe) on cyclophosphamide- (CPA-) induced immunosuppression mouse model. Methods. In total, 60 male 6-week-old ICR mice (10 mice/group) were selected based on body weight $24 \mathrm{~h}$ after the second CPA treatment and used in this experiment. Twelve hours after the end of the last (fourth) oral administration of MHFe, the animals were sacrificed. Results. Following CPA treatment, a noticeable decrease in the body, thymus, spleen, and submandibular lymph node (LN) weights; white blood cell, red blood cell, platelet number, hemoglobin, and hematocrit concentrations; serum interferon- $\gamma$ levels; splenic tumor necrosis factor- $\alpha$, interleukin- (IL-) $1 \beta$, and IL- 10 content; and peritoneal and splenic natural killer cell activities was observed. Depletion of lymphoid cells in the thymic cortex, splenic white pulp, and submandibular LN-related atrophic changes were also observed. However, these CPA-induced myelosuppressive signs were markedly and dose-dependently inhibited by the oral administration of 125, 250, and $500 \mathrm{mg} / \mathrm{kg} \mathrm{MHFe}$. Conclusion. MHFe can be a promising, potent immunomodulatory therapeutic agent for various immune disorders.
\end{abstract}

\section{Introduction}

Numerous factors can influence the immune system development, maintenance, and optimal functioning [1]. Therefore, modulation by suppressing or stimulating the immune responsiveness of an organism against the invading antigen and alleviating the disease has been of interest for many years $[2,3]$. Furthermore, many of the currently available immunomodulators, such as levamisole, glucans, telerones, and L-fucose, as well as Corynebacterium parvum bacterium, have side effects such as fever, neutropenia, leucopenia, and allergic reactions [3, 4]. Hence, identifying better agents and evaluating their immunomodulatory potential is gaining attention globally [3]. True immunomodulation includes stimulation and suppression of the immune system [2].

Nutrition impacts physiological processes in the body and nutritional status can have important implications on immune functions, resistance to infection, and autoimmunity [5]. Certain nutrients play a crucial role in the maintenance of optimum immune responses and their deficiency or excessive intake could adversely affect the number and activity of the immune cells [3]. Nutrients support the immune system by providing antioxidants. Immune cells, such as T cells, natural killer (NK) cells, and T-helper cells, are characterized by excessive levels of reactive oxygen species (ROS), which are employed, in part, to kill ingested pathogens. In addition, 
TABLE 1: Composition of MHFe used in this study.

\begin{tabular}{lcc}
\hline Herbs & Scientific names & Amounts $(\mathrm{g})$ \\
\hline Nelumbinis Semen & Nelumbo nucifera Gaertn. & 870 \\
Dioscoreae Rhizoma & Dioscorea batatas Decaisne. & 870 \\
Hoelen Alba & Poria cocos Wolf & 870 \\
Coicis Semen & Coix lacryma-jobi L. var. mayuen Stapf. & 870 \\
Hordei Fructus Germinatus & Hordeum vulgare L. & 435 \\
Lablab Semen Album & Dolichos lablab L. & 435 \\
Euryales Semen & Euryale ferox Salisb. \\
\hline Total & 7 types & 435 \\
\hline
\end{tabular}

MHFe: two-sweetener-excluded Kuseonwangdogo-based mixed herbal formula aqueous extracts.

immune cell membranes are enriched with polyunsaturated fatty acids susceptible to ROS-mediated damage $[3,6]$. Therefore, supplementation using nutrients with antioxidant properties, such as carotenes, vitamin E, vitamin C, zinc, selenium, and polyphenols, may quench these free radicals and influence several components of the immune system $[3,7,8]$. Natural herbs contain various phenolic compounds, vitamins, carotenoids, and flavonoids and have various pharmacological effects including immunomodulatory, antioxidative, antiallergic, and anticancer effects $[9,10]$. Therefore, there has been a growing interest in the field of herbal medicines and search for promising potential compounds for investigating immunomodulatory compounds from natural products in recent years [11]. Herbal drugs enhance the natural resistance of the body against infection and numerous plants have immunomodulatory activities $[12,13]$.

Kuseonwangdogo is a traditional Korean immunomodulatory polyherbal prescription [14]. It comprises seven herbs [Nelumbinis Semen (150 g), Dioscoreae Rhizoma (150 g), Hoelen Alba (150 g), Coicis Semen (150 g), Hordei Fructus Germinatus (75 g), Lablab Semen Album (75 g), and Euryales Semen (75 g)] and two sweeteners [Korean traditional sweetener, Shi-sang, prepared from dried persimmon (37.5 g) and sugar (750 g)]. Ju et al. (1999) [14] reported the in vitro anticomplementary effects of Kuseonwangdogo. Jung et al. (1996) [15] suggested that Kuseonwangdogo extracts may have immunostimulatory effects. In addition, all the seven herbal components of Kuseonwangdogo, Nelumbinis Semen [16], Dioscoreae Rhizoma [17], Hoelen Alba [18], Coicis Semen [19], Hordei Fructus Germinatus [20], Lablab Semen Album [21], and Euryales Semen [22], have been shown to have direct immunomodulatory effects or related antioxidant effects. However, there are no systemic findings on the complex immunomodulatory effects of Kuseonwangdogo extracts. In particular, CPA-induced immunosuppression mouse model has been used as valuable animal model for detecting antimutagenic or favorable immunomodulatory effects [23-25].

In this study, the immunomodulatory effects of the two sweeteners in Kuseonwangdogo-based mixed herbal formula aqueous extracts (MHFe; yield $=11.03 \%$; Table 1 ) on CPAinduced immunosuppression mouse model were observed. To induce immunosuppression in mice, CPA was intraperitoneally injected twice 3 days or 1 day before the initial test substance administration at dosages of 150 and $110 \mathrm{mg} / \mathrm{kg}$ (of body weights). Test substances were orally administered 4 times $24 \mathrm{~h}$ after second CPA treatment at $12 \mathrm{~h}$ intervals according to our previously established method [25]. $\beta$ glucan, a well-documented immunomodulatory polysaccharide, at $250 \mathrm{mg} / \mathrm{kg}$ was used as the reference drug according to previous studies [25-28]. Twelve hours after the last (fourth) oral administration of 125,250 , and $500 \mathrm{mg} / \mathrm{kg}$ MHFe or $250 \mathrm{mg} / \mathrm{kg} \beta$-glucan, changes in body, thymus, spleen, and submandibular lymph node (LN) weights, 13 hematological parameters (Table 2), serum interferon- (IFN-) $\gamma$ levels, peritoneal and splenic natural killer (NK) cell activities, and splenic tumor necrosis factor- (TNF-) $\alpha$, interleukin- (IL-) $1 \beta$, and IL-10 levels were monitored with histopathology of lymphoid organs. The total and cortex thicknesses of thymus, white pulp numbers, total and white pulp diameters of the spleen, lymphoid follicle numbers, total and cortex thicknesses of submandibular LN were the histomorphometrical parameters investigated in this study.

\section{Materials and Methods}

2.1. Animals. In total, 60 healthy male SPF ICR mice ( 6 weeks old upon receipt; Orient Bio, Seongnam, Korea; body weight 28-32 g upon receipt) were used after acclimatization for 7 days. Four animals were allocated per polycarbonate cage kept in a temperature $\left(20-25^{\circ} \mathrm{C}\right)$ and humidity $(50-55 \%)$ controlled room with $12 \mathrm{~h}$ light/dark cycle and fed standard rodent chow (Samyang, Seoul, Korea); water was available ad libitum. All laboratory animals were treated according to the international regulations for the usage and welfare of laboratory animals and the study protocol was approved by the Institutional Animal Care and Use Committee in Daegu Haany University (Gyeongsan, Gyeongbuk, Korea) [Approval Number DHU2014-068] before animal experiment. Six groups, 10 mice in each group, were selected based on the body weight deviations at $24 \mathrm{~h}$ after second CPA treatment (total 50 immunosuppressive mice, average $34.67 \pm$ $1.64 \mathrm{~g} ; 10$ intact mice, average $37.81 \pm 2.14 \mathrm{~g}$ ) and used in this experiment as follows:

\section{Experimental Groups (Eight Mice per Group Were Finally} Sacrificed)

(1) Vehicle control: distilled water-administered intact mice 
TABLE 2: Body weight gains in intact or CPA-induced immunosuppressive mice.

\begin{tabular}{|c|c|c|c|c|c|c|}
\hline \multirow[b]{3}{*}{ Groups } & \multicolumn{5}{|c|}{ Periods } & \\
\hline & \multicolumn{3}{|c|}{ Body weights at: } & \multicolumn{3}{|c|}{ Body weight gains during: } \\
\hline & $\begin{array}{c}\text { First CPA } \\
\text { treatment }[\mathrm{A}]\end{array}$ & $\begin{array}{c}\text { First/second } \\
\text { administration of test } \\
\text { substance }[\mathrm{B}]\end{array}$ & $\begin{array}{l}\text { At sacrifice } \\
{[\mathrm{C}]}\end{array}$ & $\begin{array}{l}\text { CPA treatment } \\
\text { (3 days) }[\mathrm{B}-\mathrm{A}]\end{array}$ & $\begin{array}{c}\text { Test substance } \\
\text { administration (3 days) } \\
{[\mathrm{C}-\mathrm{B}]}\end{array}$ & $\begin{array}{c}\text { Whole experimental } \\
\text { periods ( } 5 \text { days) } \\
{[\text { C-A }]}\end{array}$ \\
\hline \multicolumn{7}{|l|}{ Controls } \\
\hline Intact & $35.68 \pm 1.90$ & $37.81 \pm 2.14$ & $39.87 \pm 2.16$ & $2.13 \pm 0.94$ & $2.06 \pm 0.44$ & $4.19 \pm 1.14$ \\
\hline $\mathrm{CPA}$ & $35.64 \pm 1.91$ & $34.70 \pm 1.69^{\mathrm{a}}$ & $33.45 \pm 1.38^{\mathrm{a}}$ & $-0.94 \pm 0.81^{\mathrm{a}}$ & $-1.25 \pm 0.75^{c}$ & $-2.19 \pm 0.89^{\mathrm{a}}$ \\
\hline$\beta$-Glucan & $35.89 \pm 1.88$ & $34.83 \pm 1.70^{\mathrm{a}}$ & $36.47 \pm 1.60^{\mathrm{ab}}$ & $-1.06 \pm 0.59^{\mathrm{a}}$ & $1.64 \pm 0.35^{\mathrm{de}}$ & $0.58 \pm 0.67^{\mathrm{ab}}$ \\
\hline \multicolumn{7}{|l|}{ MHFe } \\
\hline $500 \mathrm{mg} / \mathrm{kg}$ & $35.47 \pm 1.75$ & $34.39 \pm 1.68^{\mathrm{a}}$ & $37.09 \pm 1.80^{\mathrm{ab}}$ & $-1.08 \pm 0.35^{\mathrm{a}}$ & $2.70 \pm 0.24^{\mathrm{ce}}$ & $1.62 \pm 0.32^{\mathrm{ab}}$ \\
\hline $250 \mathrm{mg} / \mathrm{kg}$ & $35.56 \pm 1.72$ & $34.75 \pm 1.60^{\mathrm{a}}$ & $36.38 \pm 1.28^{\mathrm{ab}}$ & $-0.81 \pm 0.63^{\mathrm{a}}$ & $1.63 \pm 0.79^{\mathrm{e}}$ & $0.82 \pm 0.87^{\mathrm{ab}}$ \\
\hline $125 \mathrm{mg} / \mathrm{kg}$ & $35.76 \pm 2.00$ & $34.69 \pm 1.84^{\mathrm{a}}$ & $35.68 \pm 1.60^{\mathrm{ab}}$ & $-1.07 \pm 0.61^{\mathrm{a}}$ & $0.99 \pm 0.68^{\mathrm{ce}}$ & $-0.08 \pm 0.78^{\mathrm{ab}}$ \\
\hline
\end{tabular}

Values are expressed mean \pm SD of eight mice, g; CPA: cyclophosphamide; MHFe: two-sweetener-excluded Kuseonwangdogo-based mixed herbal formula aqueous extracts; ${ }^{\mathrm{a}} p<0.01$ as compared with intact control mice by LSD test; ${ }^{\mathrm{b}} p<0.01$ as compared with CPA control mice by LSD test; ${ }^{\mathrm{c}} p<0.01$ and d $p<0.05$ as compared with intact control mice by MW test; ${ }^{\mathrm{e}} p<0.01$ as compared with CPA control mice by MW test.

\begin{tabular}{|c|c|c|}
\hline $\begin{array}{c}7 \text { days of } \\
\text { acclimatization }\end{array}$ & $\begin{array}{c}3 \text { days of } \\
\text { CPA treatment }\end{array}$ & $\begin{array}{l}2 \text { days: } \beta \text {-glucan }(250 \mathrm{mg} / \mathrm{kg}) \\
\operatorname{MHFe}(500,250 \text {, and } 125 \mathrm{mg} / \mathrm{kg})\end{array}$ \\
\hline $\begin{array}{l}\text { Male 6-week } \\
\text { ICR mice - }\end{array}$ & $\begin{array}{l}\text { Animal } \\
\text { selection }\end{array}$ & $\downarrow$ Oral administration; 4 times; $12 \mathrm{hr}$ intervals \\
\hline & $110 \mathrm{~m}$ & $\begin{array}{l}\text { Analysi: organ weights, } \quad \text { Sacrifice } \\
\text { histopathology, hematology, cytokine }\end{array}$ \\
\hline
\end{tabular}

FIgURE 1: Experimental designs used in this study. CPA: cyclophosphamide; MHFe: two-sweetener-excluded Kuseonwangdogo-based mixed herbal formula aqueous extracts.

(2) CPA control: CPA-treated and distilled wateradministered control mice

(3) $\beta$-glucan: CPA-treated and $250 \mathrm{mg} / \mathrm{kg} \quad \beta$-glucan administered mice

(4) $\mathrm{MHFe}$ 500: CPA-treated and $500 \mathrm{mg} / \mathrm{kg} \mathrm{MHFe}$ administered mice

(5) $\mathrm{MHFe}$ 250: CPA-treated and $250 \mathrm{mg} / \mathrm{kg} \mathrm{MHFe}$ administered mice

(6) MHFe 125: CPA-treated and $125 \mathrm{mg} / \mathrm{kg}$ MHFe administered mice.

2.2. Preparation and Administration of Test Materials. The two-sweetener-excluded Kuseonwangdogo-based $\mathrm{MHFe}$ (brown solution) were prepared from the appropriated mixtures $(4.785 \mathrm{~kg})$ of the seven herbs, as listed in Table 1 [Nelumbinis Semen (870 g), Dioscoreae Rhizoma (870 g), Hoelen Alba $(870 \mathrm{~g})$, Coicis Semen $(870 \mathrm{~g})$, Hordei Fructus Germinatus (435 g), Lablab Semen Album (435g), and Euryales Semen $(434 \mathrm{~g})]$, in $40 \mathrm{~L}$ of distilled water. The extracts were stored at room temperature for $8 \mathrm{~h}$. Then, they were boiled at $90^{\circ} \mathrm{C}$ for $13 \mathrm{~h}$ and filtered (200 mesh). Concentrated solutions $(30.580 \mathrm{~L})$ of $1.1^{\circ}$ Brix were obtained. Concentrated solutions, as 1.1 brix, were acquired. $\mathrm{MHFe}$ powder was prepared from this solution (yield $11.03 \%$, total weight $527.7 \mathrm{~g})$ using a rotary vacuum evaporator $(\mathrm{N}-1110$,
Eyela, Tokyo, Japan) and programmable freeze dryer (FDB5503, Operon, Kimpo, Korea) and used in this experiment as test materials. Specimens of lyophilized aqueous extracts of $\mathrm{MHFe}$ were deposited in the herbarium of the Medical Research Center for Globalization of Herbal Formulation, Daegu Haany University (Code KSWDG2014Ku01). Light brown powder of $\beta-1,3 / 1,6$-glucan purified from Aureobasidium pullulans SM2001 (Glucan Corp., Busan, Korea) was used as the reference drug. MHFe and $\beta$-glucan were stored in a refrigerator at $-20^{\circ} \mathrm{C}$ and $4^{\circ} \mathrm{C}$, respectively, until use. MHFe solution $(50 \mathrm{mg} / \mathrm{ml})$ in distilled water and $\beta$-glucan solution $(25 \mathrm{mg} / \mathrm{ml})$ in distilled water were used in this experiment.

The dosage of $\beta$-glucan was selected as $250 \mathrm{mg} / \mathrm{kg}$ based on previous in vivo efficacy tests [25-28]. The middle dosage of $\mathrm{MHFe}$ was selected as $250 \mathrm{mg} / \mathrm{kg}$ for direct comparison with $\beta$-glucan, and 500 and $125 \mathrm{mg} / \mathrm{kg}$ were selected as the highest and lowest dosages using common ratio 2 , respectively. Appropriated MHFe and $\beta$-glucan were dissolved in distilled water and orally administered at $10 \mathrm{ml} / \mathrm{kg} 4$ times at $12 \mathrm{~h}$ intervals $24 \mathrm{~h}$ after second CPA treatment. In intact and CPA control mice, $10 \mathrm{ml} / \mathrm{kg}$ of distilled water was orally administered instead of test substances according to our previously established method [25] (Table 2, Figure 1).

2.3. CPA-Induced Immunosuppression. CPA, dissolved in sterilized saline $(10 \mathrm{ml} / \mathrm{kg})$, was twice intraperitoneally 
injected 3 days or 1 day before initial test substance administration at dosages of 150 and $110 \mathrm{mg} / \mathrm{kg}$ to induce immunosuppression in mice after 7 days of acclimatization according to our previous established method [25]. In intact control mice, an equal volume of sterilized saline was intraperitoneally injected (Table 2, Figure 1).

2.4. Changes in Body Weights. Individual body weight of each mouse was measured 1 day before the first CPA treatment, at first and second CPA treatment, at first/second and third/fourth test substance administration, and $12 \mathrm{~h}$ after the fourth (last) test substance administration (at sacrifice) using an automatic electronic balance (Precisa Instrument, Dietikon, Switzerland). To reduce the individual differences, the body weight gain during 3 days of CPA treatment, 2 days of test substance administration, and 5 days of the whole experimental period was also calculated as shown below.

\section{Body Weight Gain ( $g$ )}

(1) Body weight gain during 3 days of CPA treatment = body weight at initial test substance administration body weight at the day of first CPA treatment

(2) Body weight gain during 2 days of test substance administration = body weight $12 \mathrm{~h}$ after the fourth test substance administration - body weight at initial test substance administration

(3) Body weight gain during 5 days of whole experimental period = body weight $12 \mathrm{~h}$ after the fourth test substance administration - body weight at the day of first CPA treatment.

2.5. Lymphatic Organ Weight Measurement. At sacrifice, the weights of the thymus, spleen, and left submandibular LN were measured as absolute wet-weights individually and, to reduce the differences in individual body weights, the relative weights (\% of body weights) were calculated using body weight at sacrifice and absolute weight by

$$
\begin{aligned}
& \text { Relative lymphatic organ weights }(\%) \\
& =\left(\frac{\text { Absolute organ weight }}{\text { Body weight at sacrifice }}\right) \times 100 .
\end{aligned}
$$

2.6. Hematology. About $200 \mu \mathrm{L}$ of whole blood sample was drawn from the posterior vena cava using a syringe with a 26gauge needle under 2-3\% isoflurane (Hana Pharm., Hwasung, Korea) inhalation anesthesia. The blood sample was collected into CBC bottles containing EDTA-2K (1.8 mg/mL of blood). All hematological measurements were conducted in Veterinary Teaching Hospital, College of Veterinary Medicine, Kyungpook National University (Daegu, Korea), using automated hematology cell counter (Cell-DYN3700, Abbott Laboratories, Abbott Park, IL, USA).

The 13 hematological items measured were as follows: total leukocyte numbers (WBC), differential counts (neutrophils, NEU; lymphocytes, LYM; monocytes, MONO; eosinophils, EOS; and basophils, BASO), erythrocyte numbers (RBC), hemoglobin concentrations ( $\mathrm{Hb})$, hematocrit
(Hct), mean corpuscular volume (MCV), mean corpuscular hemoglobin $(\mathrm{MCH})$, mean corpuscular hemoglobin concentration (MCHC), and platelet number (PLT).

2.7. Serum IFN- $\gamma$ Level Measurement. For serum IFN- $\gamma$ level measurement, about $0.5 \mathrm{~mL}$ of whole blood was collected from the vena cava at sacrifice under isoflurane inhalation anesthesia and centrifuged at $3,000 \mathrm{rpm}$ for $10 \mathrm{~min}$ at $4^{\circ} \mathrm{C}$ to separate the serum. All serum samples were stored at $-150^{\circ} \mathrm{C}$ in an ultradeepfreezer (Sanyo, Tokyo, Japan) until assay. Serum IFN- $\gamma$ levels were calculated using mouse IFN- $\gamma$ ELISA kit (BD Biosciences/Pharmingen, San Jose, CA, USA) according to the manufacturer's recommended protocols at $\mathrm{pg} / \mathrm{mL}$ levels.

2.8. NK Cell Activity Measurement. Splenic and peritoneal NK cell activities were measured by a standard 51Cr release assay [29-31]. In brief, all mice were sacrificed and their splenocytes and peritoneal NK cells were collected. Spleen (10-20 mg) were separated and washed with RPMI-1640 medium (Gibco BRL, Grand Island, NY, USA) twice at $4^{\circ} \mathrm{C}$ and the homogenates were prepared. Peritoneal NK cells were collected by repeated intraperitoneal wash with RPMI medium. The splenic and peritoneal NK cells were mechanically disrupted by maceration through a wire mesh (Mesh Number 100, Sigma-Aldrich Co. LLC., St. Louise, MO, USA) wetted with RPMI-1640 medium. The mesh was washed with RPMI-1640 medium to collect as many cells as possible. The debris was allowed to settle, and the cell suspension was pelleted by centrifugation. RBCs were lysed by resuspending the pellet in cold $1 \%$ ammonium oxalate and incubating on ice for $10 \mathrm{~min}$. The cells were pelleted and washed twice with Hanks Balanced Salt Solution (Gibco BRL, Grand Island, NY, USA). The peritoneal NK cells $\left(1 \times 10^{5}\right.$ cells $/ \mathrm{mL}$ to $2 \times$ $10^{5}$ cells $/ \mathrm{mL}$ ) were cultured overnight in complete medium (Sigma-Aldrich, St. Louise, MO, USA). Splenocytes were cultured overnight in Dulbecco's modified Eagle medium (Invitrogen, Grand Island, NY, USA) in the absence or presence of recombinant IL-2 (1000 IU/mL; Proleukin Chiron, Emeryville, CA, USA). The HTLA-230 neuroblastoma target cells were labeled for $2 \mathrm{~h}$ with $\mathrm{Na}_{2}{ }^{51} \mathrm{CrO}_{4}\left(100 \mu \mathrm{Ci} / \mathrm{L} \times 10^{6}\right.$ cells) (ICN Biomedicals, Asse, Belgium). Target cells were incubated for $6 \mathrm{~h}$ at $37^{\circ} \mathrm{C}$ with splenocytes or peritoneal macrophages as effector cells. The effector : target cell ratio was 100:1 for splenocytes and 10:1 for peritoneal cells. Supernatants were collected, and the amount of radioactivity released into the supernatants was counted with a gamma counter (Cobra 5002; Canberra Packard, Meriden, CT, USA). The percentage of specific target cell lysis was calculated using

$$
\begin{aligned}
& \% \text { Specific }{ }^{51} \text { Cr release (NK cell activity) } \\
& =\left[\frac{(\operatorname{Exp}-S)}{(M-S)}\right] 100 \% .
\end{aligned}
$$

Exp is the observed released ${ }^{51} \mathrm{Cr}$ value, $S$ is the spontaneously released ${ }^{51} \mathrm{Cr}$ value, and $M$ is the maximum released ${ }^{51} \mathrm{Cr}$ value. 
2.9. Splenic Cytokine Content Measurement. Splenic concentrations of TNF- $\alpha$, IL- $1 \beta$, and IL-10 were measured by ELISA using commercially available kits, mouse TNF- $\alpha$ ELISA kit (BD Biosciences/Pharmingen, San Jose, CA, USA), mouse IL- $1 \beta$ ELISA kit (Genzyme, Westborough, MA, USA), and mouse IL-10 ELISA kit (Genzyme, Westborough, MA, USA), as previously described [25, 31]. Approximately $10-15 \mathrm{mg}$ of tissue samples were homogenized in a tissue grinder containing $1 \mathrm{~mL}$ of lysis buffer (PBS containing $2 \mathrm{mM}$ PMSF and $1 \mathrm{mg} / \mathrm{mL}$ of aprotinin, leupeptin, and pepstatin $\mathrm{A}$ ) as described by Clark et al. (1991) [32]. Analysis was performed with $100 \mathrm{~mL}$ of standard (diluted in lysis buffer) or 10,50 , or $100 \mathrm{~mL}$ of tissue homogenate. Each sample was run in duplicate, and a portion of the sample was analyzed for protein. Data are expressed as $\mathrm{pg} / \mathrm{mg}$ of protein. For each assay, a standard curve was generated and, based on replicates of the measured absorbance, demonstrated an average coefficient of variance of $<10 \%$.

2.10. Histopathology. After weight measurement at sacrifice, some parts of the thymus, spleen, and left side of submandibular LN were separated and fixed in 10\% neutral buffered formalin for at least $24 \mathrm{~h}$. Then, paraffin-embedded $3 \mu \mathrm{m}$-thick sections were prepared. Each slide was stained with hematoxylin and eosin for general histopathology. Histological evaluation was performed on the central zone of each organ, whenever possible. The histopathologist was blinded to group distribution during analysis. To observe the changes in detail, the total and cortex thicknesses of thymus ( $\mu \mathrm{m} /$ thymus), total thickness of central cross trimmed spleen (from apex of anterior border to centre of posterior border; $\mathrm{mm} / \mathrm{spleen}$ ), white pulp numbers (pulps $/ \mathrm{mm}^{2}$ of spleen) and diameters ( $\mu \mathrm{m} /$ white pulps), total submandibular LN thicknesses ( $\mu \mathrm{m} /$ central regions), number of cortex lymphoid follicles (number $/ \mathrm{mm}^{2}$ of cortex), and cortex thicknesses $(\mu \mathrm{m} / \mathrm{LN})$ were also calculated using a computer-based automated image analyzer (i-Solution FL ver 9.1, IMT i-Solution Inc., Vancouver, Quebec, Canada) under a microscope (Nikon, Tokyo, Japan), according to previous report [25].

2.11. Statistical Analyses. All data were expressed as mean \pm standard deviation (SD) of 10 mice. Multiple comparison tests for different dose groups were conducted. Variance homogeneity was examined using the Levene test [33]. If the Levene test indicated no significant deviations from variance homogeneity, the obtained data were analyzed by one-way ANOVA test, followed by least-significant differences multicomparison test to determine the pairs of group comparison that were significantly different. In case a significant deviation from variance homogeneity was observed in Levene test, a nonparametric comparison test, Kruskal-Wallis $H$ test, was conducted. When a significant difference was observed in the Kruskal-Wallis $H$ test, the Mann-Whitney $U$ (MW) test was conducted to determine the specific pairs of group comparison that were significantly different. Statistical analyses were conducted using SPSS for Windows (Release $14.0 \mathrm{~K}$, IBM SPSS Inc., Armonk, NY, USA) [34]. In addition, the percent changes between intact vehicle and CPA control were calculated to observe the severity of myelosuppression induced by CPA treatment in this study, and the percent changes compared with CPA control and test substancetreated mice were calculated to understand the immunomodulatory effects of test materials using the following equations [35]:

Percentage changes compared with intact vehicle control (\%)

$$
=\left[\frac{(\text { Data of CPA control }- \text { Data of intact control mouse })}{\text { Data of intact control mouse }}\right] \times 100,
$$

Percentage changes compared with CPA control (\%)

$$
=\left[\frac{(\text { Data of test material treated mouse }- \text { Data of CPA control mouse })}{\text { Data of CPA control mouse }}\right] \times 100 \text {. }
$$

\section{Results}

3.1. Changes in Body Weight and Body Weight Gain. We selected 10 mice per group with lower body weights than intact vehicle control mice and regarded as immunosuppressed animals at the end of second CPA treatment $34.67 \pm$ $1.64 \mathrm{~g}$ of CPA-treated mice (32.1-37.8 g) and 37.81 $\pm 2.14 \mathrm{~g}$ of intact vehicle mice (34.5-41.7 g), respectively. A significant $(p<0.01)$ decrease in body weight was detected in all CPA-treated mice compared with intact vehicle control mice with significant $(p<0.01)$ decrease in body weight gain during 3 days of CPA treatment, 2 days of test substance administration, and 5 days of whole experimental period. However, a significant $(p<0.01$ or $p<0.05)$ increase in body weight was observed in $\beta$-glucan treated and 250 and $500 \mathrm{mg} / \mathrm{kg}$ MHFe-treated mice from the day of third/fourth administration and at $12 \mathrm{~h}$ after the fourth (last) administration in $125 \mathrm{mg} / \mathrm{kg}$ MHFe-treated mice compared with CPA control mice. In addition, all test substance-treated mice showed a significant $(p<0.01)$ increase in body weight gain during the 2 days of test substance administration and 5 days of whole experimental period compared with control (Table 2, Figure 2).

3.2. Changes in Thymus Weight. A significant $(p<0.01)$ decrease in absolute and relative thymus weights were observed in CPA control mice compared with intact vehicle control. However, a significant $(p<0.01)$ increase in 


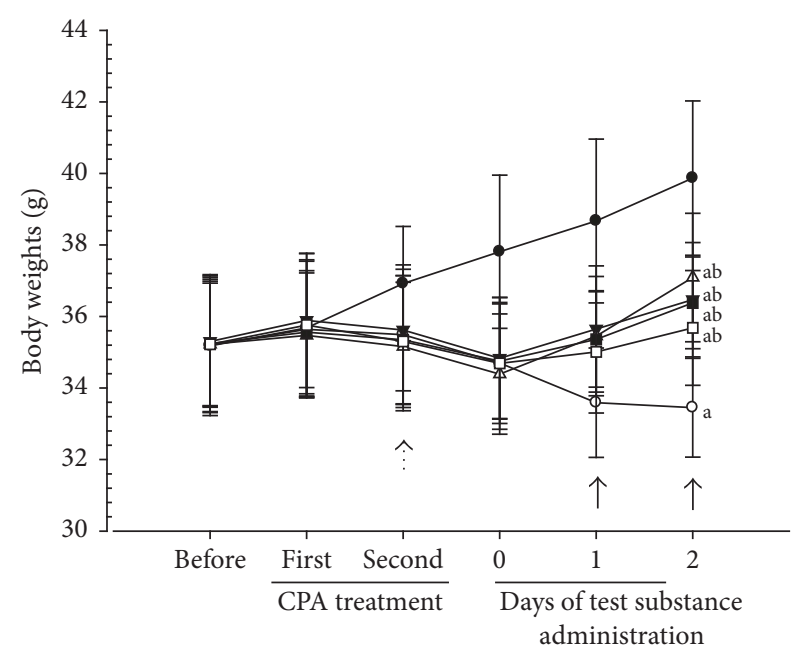

$\rightarrow$ Intact vehicle control mice

- - CPA control mice

$\rightarrow \quad \beta$-glucan $250 \mathrm{mg} / \mathrm{kg}$ treated CPA mice

$\triangle-$ MHFe $500 \mathrm{mg} / \mathrm{kg}$ treated CPA mice

- $\mathrm{MHFe} 250 \mathrm{mg} / \mathrm{kg}$ treated CPA mice

$\rightarrow-\mathrm{MHFe} 125 \mathrm{mg} / \mathrm{kg}$ treated CPA mice

FIgURE 2: Body weights changes in intact or CPA-induced immunosuppressive mice. We selected ten mice per group showing lesser body weights as compared with intact vehicle control mice, and regarded animals at end of second CPA treatment as immunosuppressive; consequently, significant $(p<0.01)$ decreases of body weights were detected in all CPA-treated mice as compared with intact vehicle control mice from first/second administration day (dot arrow). However, significant $(p<0.01$ or $p<0.05)$ increases of body weights were demonstrated in $\beta$-glucan and MHFe 500 and $250 \mathrm{mg} / \mathrm{kg}$ treated mice from the day of third/fourth administration and at $12 \mathrm{hrs}$ after last fourth administration in MHFe $125 \mathrm{mg} / \mathrm{kg}$ treated mice as compared with CPA control mice, respectively (arrows). Values are expressed mean $\pm \mathrm{SD}$ of eight mice; CPA: cyclophosphamide; MHFe: two-sweetener-excluded Kuseonwangdogo-based mixed herbal formula aqueous extracts. Before means 1 day before first CPA treatment; days 0 and 1 mean the day of first/second and third/fourth test substance administration, respectively; day 2 means the day of sacrifice, $12 \mathrm{hrs}$ after last fourth test substance administration; ${ }^{\mathrm{a}} p<0.01$ as compared with intact control mice by LSD test; ${ }^{\mathrm{b}} p<0.01$ as compared with CPA control mice by LSD test.

thymus weight was noticed in all test substance-administered mice, including $250 \mathrm{mg} / \mathrm{kg} \beta$-glucan treated mice, compared with CPA control mice. In addition, all three dosages of $\mathrm{MHFe}$ dose-dependently inhibited CPA-induced thymic weight decrease, similar to $\beta$-glucan (Table 3 ).

3.3. Changes in Spleen Weight. A significant $(p<0.01)$ decrease in absolute and relative spleen weights was observed in CPA control mice compared with intact vehicle control. However, a significant $(p<0.01)$ increase in spleen weight was detected in all test substance-administered mice compared with CPA control mice. All three dosages of MHFe dose-dependently inhibited CPA-induced splenic weight decrease, similar to $\beta$-glucan (Table 3 ).
3.4. Changes in Submandibular Lymph Node Weight. A significant $(p<0.01)$ decrease in absolute and relative liver weights was observed in CPA control mice compared with intact vehicle control. A significant $(p<0.01$ or $p<0.05)$ and dose-dependent increase in submandibular LN weight was observed in all $\mathrm{MHFe}$-treated mice compared with CPA control mice. In addition, $250 \mathrm{mg} / \mathrm{kg} \beta$-glucan significantly $(p<0.01)$ increased absolute and relative submandibular LN weights, similar to MHFe (Table 3).

3.5. Changes in Hematology. A significant $(p<0.01)$ decrease in WBC, RBC, Hb, Hct, and PLT without any meaningful change in differential WBC count, indicative of myelosuppressive nonregenerative anemia, panleukopenia, and thrombocytopenia, was observed in CPA control mice compared with intact vehicle control. However, these myelosuppressive changes in hematology were normalized by treatment with $\beta$-glucan. At the three dosages of $\mathrm{MHFe}$, the mice showed evident dose-dependent inhibitory effects on CPA-induced myelosuppressive nonregenerative anemia, panleukopenia, and thrombocytopenia, similar to $\beta$-glucantreated mice (Table 4).

3.6. Changes in Serum IFN- $\gamma$ Levels. A significant $(p<0.01)$ decrease in serum IFN- $\gamma$ levels was noticed in CPA control mice compared with intact vehicle control. All three dosages of MHFe significantly $(p<0.01$ or $p<0.05)$ and dosedependently increased serum IFN- $\gamma$ levels compared with their levels in CPA control mice. In addition, $250 \mathrm{mg} / \mathrm{kg}$ $\beta$-glucan increased serum IFN- $\gamma$ levels similar to $\mathrm{MHFe}$ (Figure 3).

3.7. Changes in NK Cell Activity. A significant $(p<0.01)$ decrease in splenic and peritoneal NK cell activities were observed in CPA control mice compared with intact vehicle control mice. However, a significant $(p<0.01$ or $p<$ 0.05 ) increase in splenic and peritoneal NK cell activities was detected in all test substance-administered mice, including the reference drug $250 \mathrm{mg} / \mathrm{kg} \beta$-glucan treated mice, compared with CPA control mice. All three dosages of $\mathrm{MHFe}$ exhibited a clear dose-dependent inhibitory effect on CPAinduced decrease in $\mathrm{NK}$ cell activities, similar to $\beta$-glucan (Figure 4).

3.8. Changes in Splenic Cytokine Content. A significant $(p<$ 0.01 ) decrease in splenic TNF- $\alpha$, IL- $1 \beta$, and IL-10 content was observed in CPA control mice compared with intact vehicle control. However, a significant $(p<0.01$ or $p<$ 0.05 ) increase in splenic TNF- $\alpha$, IL- $1 \beta$, and IL-10 content was detected in all test substance-administered mice, including those given the lowest dosage $(125 \mathrm{mg} / \mathrm{kg})$ of $\mathrm{MHFe}$, compared with CPA control mice. All three dosages of $\mathrm{MHFe}$ showed a clear dose-dependent inhibitory effect on CPAinduced decrease in splenic cytokines, similar to $\beta$-glucan (Table 5).

3.9. Effects on Lymphoid Organ Histopathology. Atrophic changes related to the decrease in thymic cortex lymphoid 
TABLE 3: Organ weights in intact or CPA-induced immunosuppressive mice.

\begin{tabular}{|c|c|c|c|c|c|c|}
\hline \multirow{3}{*}{ Groups } & \multicolumn{6}{|c|}{ Organs } \\
\hline & \multicolumn{3}{|c|}{ Absolute weights (g) } & \multicolumn{3}{|c|}{ Relative weights (\% of body weights) } \\
\hline & Thymus & Spleen & $\mathrm{LN}$ & Thymus & Spleen & $\mathrm{LN}$ \\
\hline \multicolumn{7}{|l|}{ Controls } \\
\hline Intact & $0.068 \pm 0.012$ & $0.115 \pm 0.019$ & $0.021 \pm 0.006$ & $0.171 \pm 0.034$ & $0.288 \pm 0.053$ & $0.052 \pm 0.012$ \\
\hline $\mathrm{CPA}$ & $0.016 \pm 0.003^{\mathrm{d}}$ & $0.046 \pm 0.010^{\mathrm{d}}$ & $0.005 \pm 0.002^{\mathrm{d}}$ & $0.047 \pm 0.010^{\mathrm{d}}$ & $0.136 \pm 0.029^{\mathrm{d}}$ & $0.014 \pm 0.007^{\mathrm{a}}$ \\
\hline$\beta$-Glucan & $0.028 \pm 0.006^{\mathrm{de}}$ & $0.067 \pm 0.010^{\mathrm{de}}$ & $0.010 \pm 0.003^{\mathrm{de}}$ & $0.077 \pm 0.015^{\mathrm{de}}$ & $0.183 \pm 0.027^{\mathrm{de}}$ & $0.027 \pm 0.009^{\mathrm{ab}}$ \\
\hline \multicolumn{7}{|l|}{$\mathrm{MHFe}$} \\
\hline $500 \mathrm{mg} / \mathrm{kg}$ & $0.035 \pm 0.009^{\mathrm{de}}$ & $0.079 \pm 0.014^{\mathrm{de}}$ & $0.012 \pm 0.003^{\mathrm{de}}$ & $0.095 \pm 0.027^{\mathrm{de}}$ & $0.213 \pm 0.037^{\mathrm{de}}$ & $0.038 \pm 0.008^{\mathrm{ab}}$ \\
\hline $250 \mathrm{mg} / \mathrm{kg}$ & $0.027 \pm 0.008^{\mathrm{de}}$ & $0.066 \pm 0.010^{\mathrm{de}}$ & $0.010 \pm 0.002^{\mathrm{de}}$ & $0.074 \pm 0.021^{\mathrm{de}}$ & $0.182 \pm 0.026^{\mathrm{de}}$ & $0.026 \pm 0.006^{\mathrm{ab}}$ \\
\hline $125 \mathrm{mg} / \mathrm{kg}$ & $0.022 \pm 0.004^{\mathrm{de}}$ & $0.061 \pm 0.009^{\mathrm{de}}$ & $0.008 \pm 0.002^{\mathrm{de}}$ & $0.061 \pm 0.011^{\mathrm{de}}$ & $0.171 \pm 0.021^{\mathrm{de}}$ & $0.023 \pm 0.006^{\mathrm{ac}}$ \\
\hline
\end{tabular}

Values are expressed mean \pm SD of eight mice; CPA: cyclophosphamide; MHFe: two-sweetener-excluded Kuseonwangdogo-based mixed herbal formula aqueous extracts; LN: submandibular lymph node, left side; ${ }^{\mathrm{a}} p<0.01$ as compared with intact control mice by LSD test; ${ }^{\mathrm{b}} p<0.01$ and ${ }^{\mathrm{c}} p<0.05$ compared with CPA control mice by LSD test; ${ }^{\mathrm{d}} p<0.01$ as compared with intact control mice by MW test; ${ }^{\mathrm{e}} p<0.01$ as compared with CPA control mice by MW test.

TABLE 4: Hematological values in intact or CPA-induced immunosuppressive mice.

\begin{tabular}{|c|c|c|c|c|c|c|}
\hline \multirow{3}{*}{ Items } & \multicolumn{6}{|c|}{ Groups } \\
\hline & \multicolumn{3}{|c|}{ Controls } & \multicolumn{3}{|c|}{ MHFe } \\
\hline & Intact & $\mathrm{CPA}$ & $\beta$-glucan & $500 \mathrm{mg} / \mathrm{kg}$ & $250 \mathrm{mg} / \mathrm{kg}$ & $125 \mathrm{mg} / \mathrm{kg}$ \\
\hline $\mathrm{WBC}(\mathrm{K} / \mu \mathrm{l})$ & $7.51 \pm 1.73$ & $0.30 \pm 0.11^{c}$ & $0.85 \pm 0.17^{\mathrm{cd}}$ & $1.24 \pm 0.64^{\mathrm{cd}}$ & $0.83 \pm 0.16^{\mathrm{cd}}$ & $0.63 \pm 0.12^{\text {cd }}$ \\
\hline \multicolumn{7}{|c|}{ Differential count } \\
\hline LYM\% & $74.83 \pm 9.73$ & $74.80 \pm 6.83$ & $74.41 \pm 10.72$ & $73.51 \pm 10.40$ & $74.91 \pm 7.40$ & $74.61 \pm 9.74$ \\
\hline NEU\% & $18.40 \pm 8.88$ & $18.97 \pm 6.96$ & $18.84 \pm 10.89$ & $20.02 \pm 10.80$ & $18.88 \pm 7.42$ & $19.01 \pm 10.04$ \\
\hline MONO\% & $4.73 \pm 1.80$ & $4.66 \pm 1.24$ & $4.52 \pm 1.68$ & $4.64 \pm 2.03$ & $4.64 \pm 1.72$ & $4.68 \pm 1.40$ \\
\hline EOS\% & $0.50 \pm 0.70$ & $0.49 \pm 0.44$ & $0.47 \pm 0.46$ & $0.50 \pm 0.52$ & $0.48 \pm 0.42$ & $0.50 \pm 0.54$ \\
\hline BASO $\%$ & $0.54 \pm 0.54$ & $0.55 \pm 0.55$ & $0.56 \pm 0.49$ & $0.55 \pm 0.47$ & $0.54 \pm 0.46$ & $0.54 \pm 0.36$ \\
\hline $\mathrm{RBC}(\mathrm{M} / \mu \mathrm{l})$ & $9.16 \pm 1.17$ & $5.91 \pm 1.03^{c}$ & $7.21 \pm 0.38^{\mathrm{cd}}$ & $7.79 \pm 0.36^{\mathrm{cd}}$ & $7.30 \pm 0.52^{\mathrm{cd}}$ & $7.01 \pm 0.42^{\mathrm{cd}}$ \\
\hline $\mathrm{Hb}(\mathrm{g} / \mathrm{dl})$ & $18.87 \pm 1.50$ & $13.63 \pm 1.84^{\mathrm{c}}$ & $16.62 \pm 0.57^{\mathrm{cd}}$ & $17.30 \pm 0.79^{\mathrm{cd}}$ & $16.64 \pm 0.84^{\mathrm{cd}}$ & $16.01 \pm 0.91^{\mathrm{cd}}$ \\
\hline Hct $(\%)$ & $47.43 \pm 1.62$ & $40.62 \pm 0.46^{\mathrm{c}}$ & $42.02 \pm 0.77^{\mathrm{cd}}$ & $43.22 \pm 0.85^{\mathrm{cd}}$ & $42.04 \pm 0.48^{\mathrm{cd}}$ & $41.64 \pm 0.89^{\mathrm{cd}}$ \\
\hline $\operatorname{MCV}(\mathrm{fl})$ & $51.96 \pm 1.84$ & $51.76 \pm 3.05$ & $52.08 \pm 2.36$ & $51.79 \pm 1.87$ & $52.08 \pm 2.81$ & $52.20 \pm 2.88$ \\
\hline $\mathrm{MCH}(\mathrm{pg})$ & $18.01 \pm 1.05$ & $17.93 \pm 0.95$ & $18.03 \pm 1.24$ & $17.86 \pm 1.53$ & $18.17 \pm 1.83$ & $17.89 \pm 1.48$ \\
\hline MCHC (g/dl) & $19.28 \pm 1.14$ & $19.30 \pm 1.69$ & $19.40 \pm 1.62$ & $19.20 \pm 1.26$ & $19.38 \pm 1.72$ & $19.28 \pm 1.06$ \\
\hline $\operatorname{PLT}(\mathrm{M} / \mu \mathrm{l})$ & $1501.00 \pm 115.25$ & $965.70 \pm 116.63^{\mathrm{a}}$ & $1162.90 \pm 86.95^{\mathrm{ab}}$ & $1259.80 \pm 121.90^{\mathrm{ab}}$ & $1157.30 \pm 129.42^{\mathrm{ab}}$ & $1113.00 \pm 106.78^{\mathrm{ab}}$ \\
\hline
\end{tabular}

Values are expressed mean \pm SD of eight mice. Full name of hematological items were listed in Table 2; CPA: cyclophosphamide. MHFe: two-sweetenerexcluded Kuseonwangdogo-based mixed herbal formula aqueous extracts; WBC: white blood cell, LYM: lymphocytes, NEU: neutrophils, MONO: monocytes, EOS: eosinophils, BASO: basophils, RBC: red blood cell, Hb: hemoglobin concentration, Hct: hematocrit, MCV: mean corpuscular volume, MCH: mean corpuscular hemoglobin, MCHC: mean corpuscular hemoglobin concentration, and PLT: platelet count; ${ }^{\mathrm{a}} p<0.01$ as compared with intact control mice by LSD test; ${ }^{\mathrm{b}} p<0.01$ as compared with CPA control mice by LSD test; ${ }^{\mathrm{c}} p<0.01$ as compared with intact control mice by MW test; ${ }^{\mathrm{d}} p<0.01$ as compared with CPA control mice by MW test.

cells were detected in CPA control mice compared with intact vehicle control mice. Consequently, the total thymus and cortex thicknesses significantly $(p<0.01)$ decreased in CPA control mice compared with intact vehicle control mice. However, these thymic atrophic changes were significantly $(p<0.01)$ inhibited by treatment with $\beta$-glucan and all three dosages of MHFe compared with CPA control mice. The three dosages of MHFe dose-dependently inhibited CPA-induced histopathological atrophic changes of the thymus, similar to $\beta$-glucan (Table 6, Figure 5).

3.10. Effects on Splenic Histopathology. Atrophic changes related to the decrease in splenic white pulp lymphoid cells were detected in CPA control mice compared with intact vehicle control mice. The total spleen thickness, white pulp numbers, and diameters were significantly $(p<0.01)$ lower in CPA control mice than in intact control mice. However, these splenic atrophic changes were markedly inhibited by treatment with $\beta$-glucan and 125, 250, and $500 \mathrm{mg} / \mathrm{kg} \mathrm{MHFe}$ compared with CPA control mice. All three dosages of $\mathrm{MHFe}$ showed noticeable dose-dependent inhibitory effect on CPAinduced histopathological atrophic changes in the spleen, similar to $\beta$-glucan (Table 6, Figure 6).

3.11. Effects on Submandibular Lymph Node Histopathology. A decrease in lymphoid cell-related atrophic changes was detected in the submandibular LN of CPA control mice compared with intact control mice. The total and cortex 
TABLE 5: Changes in the splenic cytokine contents in intact or CPA-induced immunosuppressive mice.

\begin{tabular}{lccc}
\hline Groups & & $\begin{array}{c}\text { Cytokines } \\
\text { Splenic cytokine contents (pg/ml) } \\
\text { Interleukin-1 } \beta\end{array}$ & Interleukin-10 \\
\hline Controls & $117.28 \pm 24.00$ & $67.90 \pm 13.36$ & $96.56 \pm 24.33$ \\
Intact & $39.42 \pm 15.85^{\mathrm{a}}$ & $20.75 \pm 10.49^{\mathrm{a}}$ & $34.47 \pm 14.55^{\mathrm{a}}$ \\
CPA & $66.03 \pm 18.46^{\mathrm{ab}}$ & $37.55 \pm 11.83^{\mathrm{ab}}$ & $61.73 \pm 10.77^{\mathrm{ab}}$ \\
$\beta$-Glucan & & & $74.23 \pm 12.51^{\mathrm{ab}}$ \\
MHFe & $89.77 \pm 15.49^{\mathrm{ab}}$ & $50.49 \pm 13.55^{\mathrm{ab}}$ & $61.08 \pm 14.06^{\mathrm{ab}}$ \\
$500 \mathrm{mg} / \mathrm{kg}$ & $67.25 \pm 13.71^{\mathrm{ab}}$ & $38.59 \pm 12.40^{\mathrm{ab}}$ & $53.84 \pm 13.69^{\mathrm{ac}}$ \\
$250 \mathrm{mg} / \mathrm{kg}$ & $57.09 \pm 11.12^{\mathrm{ac}}$ & $33.87 \pm 9.11^{\mathrm{ac}}$ & \\
$125 \mathrm{mg} / \mathrm{kg}$ & & & \\
\hline
\end{tabular}

Values are expressed mean \pm SD of eight mice, pg/ml; CPA: cyclophosphamide; MHFe: two-sweetener-excluded Kuseonwangdogo-based mixed herbal formula aqueous extracts; ${ }^{\mathrm{a}} p<0.01$ as compared with intact control mice by LSD test; ${ }^{\mathrm{b}} p<0.01$ and ${ }^{\mathrm{c}} p<0.05$ compared with CPA control mice by LSD test.

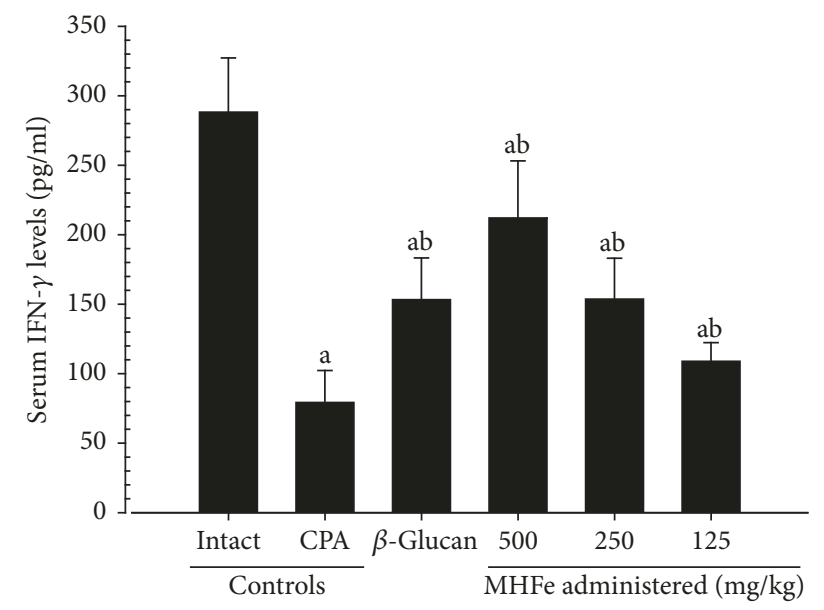

FIGURE 3: Serum IFN- $\gamma$ levels in intact or CPA-induced immunosuppressive mice. Significant decreases of serum IFN- $\gamma$ levels were noticed in CPA control mice as compared with intact vehicle control, respectively. All three different dosages of MHFe showed significant and clear dose-dependent increases of serum IFN- $\gamma$ levels as compared with CPA control mice, respectively. In addition, $\beta$-glucan $250 \mathrm{mg} / \mathrm{kg}$ administered mice also showed increases of serum IFN- $\gamma$ levels comparable to those of equal dosages of MHFe administered mice, in this study; values are expressed mean \pm SD of eight mice; CPA: cyclophosphamide; MHFe: two-sweetenerexcluded Kuseonwangdogo-based mixed herbal formula aqueous extracts; IFN: interferon; ${ }^{\mathrm{a}} p<0.01$ as compared with intact control mice by LSD test; ${ }^{\mathrm{b}} p<0.01$ as compared with CPA control mice by LSD test.

thicknesses and follicle numbers were significantly $(p<$ 0.01) lower in CPA control mice than in intact control mice. However, these submandibular LN atrophic changes were significantly $(p<0.01$ or $p<0.05)$ inhibited by treatment with all test substances, including $250 \mathrm{mg} / \mathrm{kg} \beta$-glucan, compared with CPA control mice. All three dosages of $\mathrm{MHFe}$ dose-dependently inhibited CPA-induced histopathological atrophic changes in the submandibular LN, similar to $\beta$ glucan (Table 6, Figure 7).

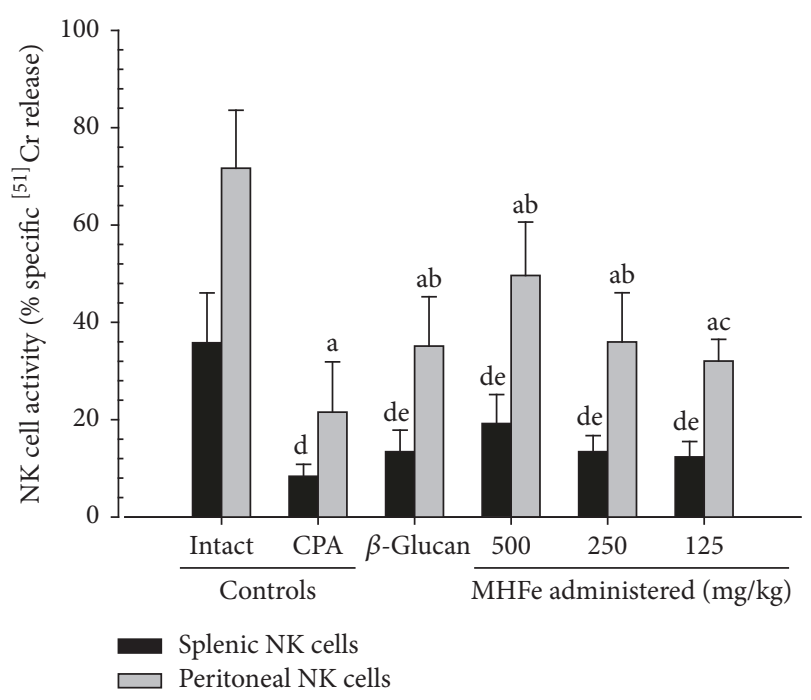

FIGURE 4: NK cell activities in intact or CPA-induced immunosuppressive mice. Significant decreases of splenic and peritoneal NK cell activities were observed in CPA control mice as compared with intact vehicle control mice, respectively. However, significant increases of splenic and peritoneal NK cell activities were detected in all test substance-administered mice including $\beta$-glucan $250 \mathrm{mg} / \mathrm{kg}$ oral administered mice as compared with CPA control mice, respectively. All three different dosages of MHFe-treated mice, especially, showed obvious dose-dependent inhibitory effects on CPA-induced decreases of NK cell activities as similar as equal dosages of $\beta$-glucan, in this experiment; values are expressed mean \pm SD of eight mice; CPA: cyclophosphamide; MHFe: two-sweetenerexcluded Kuseonwangdogo-based mixed herbal formula aqueous extracts; NK: natural killer; ${ }^{a} p<0.01$ as compared with intact control mice by LSD test; ${ }^{\mathrm{b}} p<0.01$ and ${ }^{\mathrm{c}} p<0.05$ as compared with CPA control mice by LSD test; ${ }^{\mathrm{d}} p<0.01$ as compared with intact control mice by MW test; ${ }^{\mathrm{e}} p<0.01$ as compared with CPA control mice by MW test.

\section{Discussion}

Immune functions are indispensable as they constitute the host defenses against infections and therefore play a crucial 


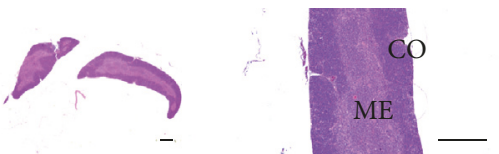

(a)
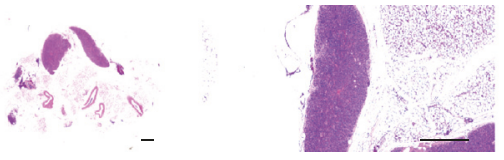

(c)
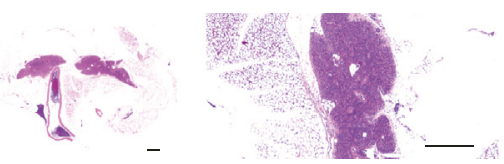

(e)
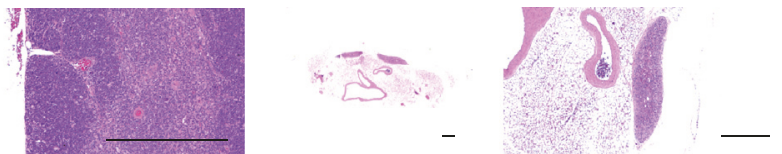

(b)
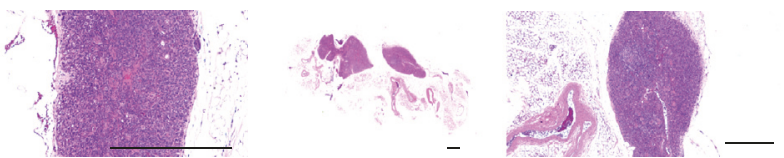

(d)
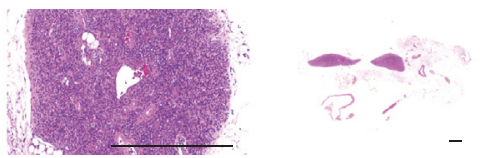

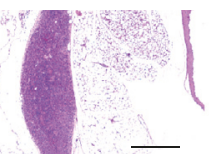

(f)
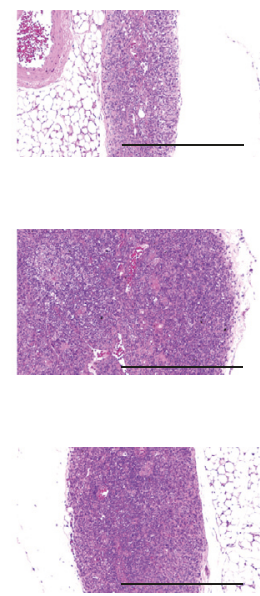

FIGURE 5: Representative histopathological images of the thymus, taken from intact or CPA-induced immunosuppressive mice. Noticeable atrophic changes related to the decrease of thymic cortex lymphoid cells were detected in CPA control mice as compared with intact vehicle control mice; consequently the thymus total and cortex thicknesses were significantly decreased in CPA control mice as compared with intact vehicle control mice, respectively. However, these thymic atrophic changes were significantly inhibited by treatment of $\beta$-glucan and all three different dosages of MHFe as compared with CPA control mice, respectively. All three different dosages of MHFe-treated mice, especially, showed obvious dose-dependent inhibitory effects on CPA-induced histopathological atrophic changes of the thymus similar to equal dosages of $\beta$-glucan, in this experiment; (a) distilled water-administered intact mice (vehicle control); (b) CPA-treated and distilled water-administered control mice (CPA control); (c) CPA-treated and $\beta$-glucan $250 \mathrm{mg} / \mathrm{kg}$ administered mice ( $\beta$-glucan); (d) CPA-treated and MHFe $500 \mathrm{mg} / \mathrm{kg}$ administered mice (MHFe 500); (e) CPA-treated and MHFe $250 \mathrm{mg} / \mathrm{kg}$ administered mice (MHFe 250); (f) CPA-treated and MHFe $125 \mathrm{mg} / \mathrm{kg}$ administered mice (MHFe 125); CPA: cyclophosphamide; MHFe: two-sweetener-excluded Kuseonwangdogo-based mixed herbal formula aqueous extracts; CO: cortex; ME: medulla; all Hematoxylin-Eosin stain; scale bar: $400 \mu \mathrm{m}$.
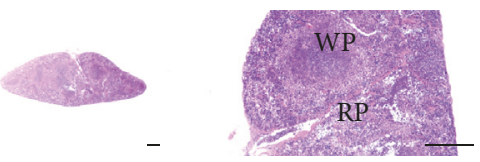

(a)

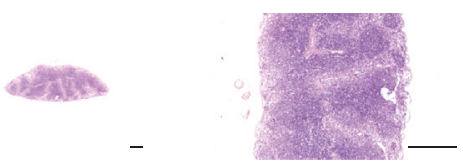

(c)

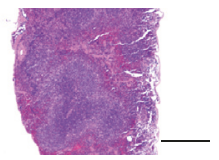

(e)
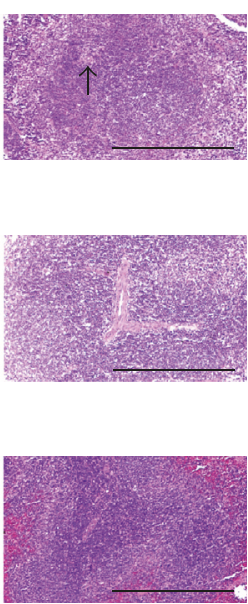
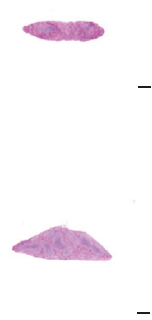

$-$

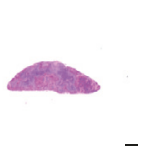

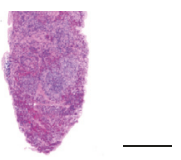

(b)

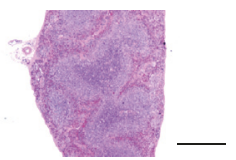

(d)

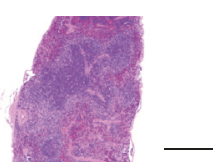

(f)
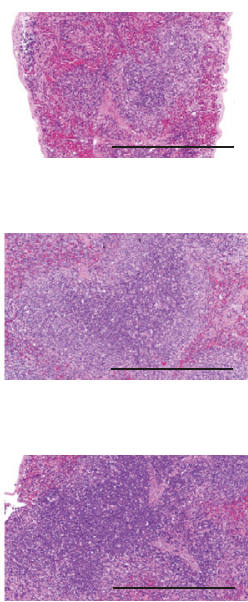

FiguRE 6: Representative histopathological images of the spleen, taken from intact or CPA-induced immunosuppressive mice. Obvious atrophic changes related to the decrease of splenic white pulp lymphoid cells were detected in CPA control mice as compared with intact vehicle control mice; consequently the total splenic thicknesses and white pulp numbers and diameters were significantly decreased in CPA control mice as compared with intact control mice, respectively. However, these splenic atrophic changes were markedly inhibited by treatment of $\beta$-glucan and MHFe 500, 250, and $125 \mathrm{mg} / \mathrm{kg}$ as compared with CPA control mice, respectively. All three different dosages of MHFetreated mice, especially, showed clear and noticeable dose-dependent inhibitory effects on CPA-induced histopathological atrophic changes of the spleen similar to equal dosages of $\beta$-glucan, in this experiment; (a) distilled water-administered intact mice (vehicle control); (b) CPA-treated and distilled water-administered control mice (CPA control); (c) CPA-treated and $\beta$-glucan $250 \mathrm{mg} / \mathrm{kg}$ administered mice ( $\beta$ glucan); (d) CPA-treated and MHFe $500 \mathrm{mg} / \mathrm{kg}$ administered mice (MHFe 500); (e) CPA-treated and MHFe $250 \mathrm{mg} / \mathrm{kg}$ administered mice (MHFe 250); (f) CPA-treated and MHFe $125 \mathrm{mg} / \mathrm{kg}$ administered mice (MHFe 125); CPA: cyclophosphamide; MHFe: two-sweetener-excluded Kuseonwangdogo-based mixed herbal formula aqueous extracts; WP: white pulp; RP: red pulps; arrow: central arteriole; all HematoxylinEosin stain; scale bar: $400 \mu \mathrm{m}$. 
TABLE 6: Histomorphometrical analysis in intact or CPA-induced immunosuppressive mice.

\begin{tabular}{|c|c|c|c|c|c|c|}
\hline \multirow{3}{*}{ Items } & \multicolumn{6}{|c|}{ Groups } \\
\hline & \multicolumn{3}{|c|}{ Controls } & \multicolumn{3}{|c|}{ MHFe } \\
\hline & Intact & CPA & $\beta$-glucan & $500 \mathrm{mg} / \mathrm{kg}$ & $250 \mathrm{mg} / \mathrm{kg}$ & $125 \mathrm{mg} / \mathrm{kg}$ \\
\hline \multicolumn{7}{|l|}{ Thymus-thickness } \\
\hline Total $(\mu \mathrm{m})$ & $756.66 \pm 152.51$ & $221.18 \pm 61.77^{\mathrm{a}}$ & $464.30 \pm 82.11^{\mathrm{a}}$ & $650.03 \pm 113.44^{b c}$ & $465.12 \pm 103.29^{\mathrm{ac}}$ & $353.65 \pm 108.21^{\mathrm{ac}}$ \\
\hline Cortex $(\mu \mathrm{m})$ & $291.95 \pm 90.11$ & $50.23 \pm 17.40^{\mathrm{a}}$ & $132.10 \pm 38.87^{\mathrm{ac}}$ & $196.10 \pm 30.33^{\mathrm{ac}}$ & $133.30 \pm 26.84^{\mathrm{ac}}$ & $106.36 \pm 19.50^{\mathrm{ac}}$ \\
\hline \multicolumn{7}{|l|}{ Spleen-thickness } \\
\hline Total $(\mu \mathrm{m})$ & $1882.93 \pm 211.98$ & $773.40 \pm 173.96^{\mathrm{a}}$ & $1220.70 \pm 113.88^{\mathrm{ac}}$ & $1320.15 \pm 155.10^{\text {ac }}$ & $1216.14 \pm 98.56^{\mathrm{ac}}$ & $1063.07 \pm 150.82^{\mathrm{ac}}$ \\
\hline Cortex $(\mu \mathrm{m})$ & $413.46 \pm 55.59$ & $185.92 \pm 47.26^{\mathrm{e}}$ & $298.46 \pm 22.99^{\mathrm{eg}}$ & $350.14 \pm 55.58^{\mathrm{fg}}$ & $304.31 \pm 20.94^{\mathrm{eg}}$ & $260.68 \pm 34.28^{\mathrm{eg}}$ \\
\hline WP number $\left(/ \mathrm{mm}^{2}\right)$ & $15.60 \pm 3.10$ & $4.70 \pm 1.57^{\mathrm{e}}$ & $9.20 \pm 1.48^{\mathrm{eg}}$ & $13.70 \pm 2.00^{\mathrm{g}}$ & $9.40 \pm 1.51^{\mathrm{eg}}$ & $7.90 \pm 1.10^{\mathrm{eg}}$ \\
\hline \multicolumn{7}{|l|}{ LN-thickness } \\
\hline Total $(\mu \mathrm{m})$ & $1198.93 \pm 126.22$ & $472.08 \pm 112.35^{\mathrm{a}}$ & $861.22 \pm 135.38^{\mathrm{ac}}$ & $994.86 \pm 128.55^{\mathrm{ac}}$ & $891.35 \pm 131.31^{\mathrm{ac}}$ & $615.36 \pm 80.32^{\mathrm{ad}}$ \\
\hline Cortex $(\mu \mathrm{m})$ & $867.66 \pm 106.04$ & $286.07 \pm 104.07^{\mathrm{a}}$ & $594.14 \pm 145.05^{\mathrm{ac}}$ & $737.86 \pm 130.89^{b c}$ & $671.25 \pm 123.16^{\mathrm{ac}}$ & $320.09 \pm 97.73^{\mathrm{ad}}$ \\
\hline Follicle number $\left(/ \mathrm{mm}^{2}\right)$ & $12.70 \pm 2.41$ & $2.70 \pm 1.95^{\mathrm{a}}$ & $8.90 \pm 1.29^{\mathrm{ac}}$ & $10.50 \pm 1.58^{\mathrm{ac}}$ & $9.00 \pm 1.70^{\mathrm{ac}}$ & $4.90 \pm 1.20^{\mathrm{ac}}$ \\
\hline
\end{tabular}

Values are expressed mean \pm SD of eight mice; CPA: cyclophosphamide; MHFe: two-sweetener-excluded Kuseonwangdogo-based mixed herbal formula aqueous extracts; WP: White pulp; LN: submandibular lymph node, left sides; ${ }^{\mathrm{a}} p<0.01$ and ${ }^{\mathrm{b}} p<0.05$ as compared with intact control mice by LSD test; ${ }^{\mathrm{c}} p<0.01$ and ${ }^{\mathrm{d}} p<0.05$ as compared with CPA control mice by LSD test; ${ }^{\mathrm{e}} p<0.01$ and ${ }^{\mathrm{f}} p<0.05$ as compared with intact control mice by MW test; ${ }^{\mathrm{g}} p<0.01$ as compared with CPA control mice by MW test.

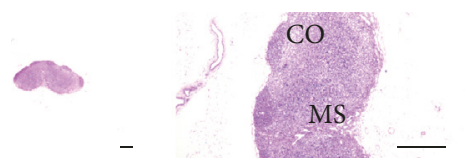

(a)

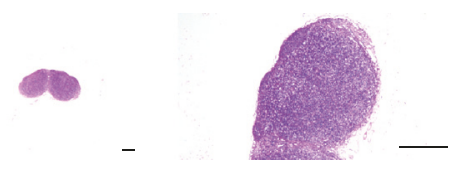

(c)

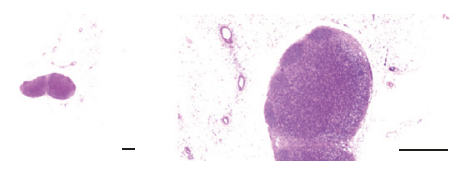

(e)
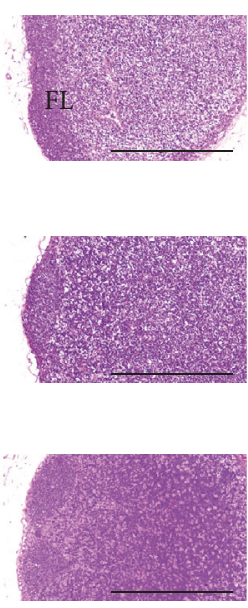

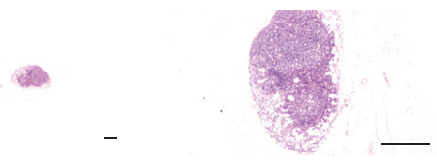

(b)

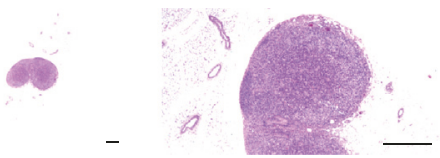

(d)

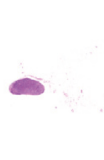

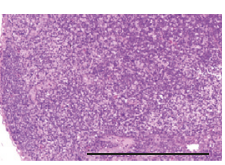

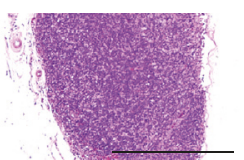

(f)

FIGURE 7: Representative histopathological images of the left submandibular LN, taken from intact or CPA-induced immunosuppressive mice. Diffused decreases of lymphoid cell-related atrophic changes were detected in the submandibular LN of CPA control mice as compared with intact control mice; consequently the total and cortex thicknesses and follicle numbers were significantly decreased in CPA control mice as compared with intact control mice, respectively. However, these submandibular lymph node atrophic changes were markedly and significantly inhibited by treatment of all test substances including $\beta$-glucan $250 \mathrm{mg} / \mathrm{kg}$ as compared with CPA control mice, and all three dosages of MHFe-treated mice, especially, showed clear dose-dependent inhibitory effects on CPA-induced histopathological atrophic changes of the submandibular LN similar to equal dosages of $\beta$-glucan, in this experiment; (a) distilled water-administered intact mice (vehicle control); (b) CPA-treated and distilled water-administered control mice (CPA control); (c) CPA-treated and $\beta$-glucan $250 \mathrm{mg} / \mathrm{kg}$ administered mice ( $\beta$-glucan); (d) CPA-treated and MHFe $500 \mathrm{mg} / \mathrm{kg}$ administered mice (MHFe 500); (e) CPA-treated and MHFe $250 \mathrm{mg} / \mathrm{kg}$ administered mice (MHFe 250); (f) CPA-treated and MHFe $125 \mathrm{mg} / \mathrm{kg}$ administered mice (MHFe 125); CPA: cyclophosphamide; MHFe: two-sweetenerexcluded Kuseonwangdogo-based mixed herbal formula aqueous extracts; LN: lymph node; CO: cortex; MS: medullary sinus; FL: follicle; all Hematoxylin-Eosin stain; scale bar: $400 \mu \mathrm{m}$.

role in maintaining health [36]. Decline in immune functions due to aging, chronic illnesses, physical and mental stress, or unhealthy lifestyles is a major clinical problem globally [3638]. Drugs that normalize or modulate pathophysiological processes are known as immunomodulatory agents [39]. In recent years, there has been growing interest in the field of herbal medicine and search for promising compounds for identifying immunomodulatory compounds from natural products [11]. Herbal drugs enhance the natural resistance of the body against infection and their immunomodulatory activities have been reported in numerous plants $[12,13]$. In this study, we observed the immunomodulatory effects of 
MHFe of two-sweetener-excluded Kuseonwangdogo, a traditional Korean immunomodulatory polyherbal prescription [14], on CPA-induced immunosuppressive mouse model. To induce immunosuppression in mice, CPA was intraperitoneally injected twice 3 days or 1 day before the initial test substance administration at 150 and $110 \mathrm{mg} / \mathrm{kg}$. Test substances were orally administered 4 times $24 \mathrm{~h}$ after second CPA treatment at $12 \mathrm{~h}$ intervals, according to our previously established method [25]. $\beta$-glucan, a well-documented immunomodulatory polysaccharide [40], was used as the reference drug according to previous studies [25-28]. Twelve hours after the last (fourth) oral administration of the three dosages $(125,250$, and $500 \mathrm{mg} / \mathrm{kg}$ ) of MHFe or $250 \mathrm{mg} / \mathrm{kg}$ of $\beta$-glucan, changes in the body, thymus, spleen, and submandibular LN weights, 13 hematological parameters, serum IFN- $\gamma$ levels, peritoneal and splenic NK cell activities, and splenic TNF- $\alpha$, IL-1 $\beta$, and IL-10 levels were monitored with histopathology of lymphoid organs. The total and cortex thicknesses of thymus, white pulp numbers, total and white pulp diameters of the spleen, lymphoid follicle numbers, and total and cortex thicknesses of submandibular LN were the histomorphometrical parameters evaluated in this study.

The dosage of $\beta$-glucan was selected as $250 \mathrm{mg} / \mathrm{kg}$ on the basis of previous in vivo efficacy tests [25-28]. The middle dosage of MHFe was selected as $250 \mathrm{mg} / \mathrm{kg}$ for direct comparison with $\beta$-glucan, and 500 and $125 \mathrm{mg} / \mathrm{kg}$ were selected as the highest and lowest dosages using common ratio 2 , respectively.

Following CPA treatment in mice, a noticeable decrease in body weight and body weight gain, thymus, spleen, and submandibular LN weights, WBC, RBC, PLT, $\mathrm{Hb}$, and $\mathrm{Hct}$, serum IFN- $\gamma$ levels, splenic TNF- $\alpha$, IL- $1 \beta$, and IL-10 content, and peritoneal and splenic NK cell activities was observed. In addition, depletion of lymphoid cells in thymic cortex, splenic white pulp, and submandibular LN-related atrophic changes of the lymphoid organs were observed, which suggested classic CPA-induced myelosuppression with nonregenerative anemia. However, these CPA-induced myelosuppression signs were dose-dependently inhibited by the oral administration of 125,25 , and $500 \mathrm{mg} / \mathrm{kg}$ MHFe compared with $\beta$-glucan. These results are direct evidence that MHFe has favorable immunomodulatory effects on CPA-induced myelosuppression and indicate that Kuseonwangdogo-based MHFe can be a potent immunomodulatory agent for treatment of various immune disorders.

Noticeable decrease in body weights has been observed after treatment with CPA by other investigators, indicating its direct toxicity [25,41, 42], as well as decrease in lymphatic organ weight related to myelosuppressive depletion of peripheral lymphoid cells [11, 25, 43]. In this experiment, we also selected immunosuppressed animals based on lower body weight than intact vehicle control mice at the end of second CPA treatment. Consequently, a significant decrease in body weight was detected in all CPA-treated mice compared with intact vehicle control mice with significant decrease in body weight gain during 3 days of CPA treatment, 2 days of test substance treatment, and 5 days of whole experimental period. In addition, a significant decrease in thymus, spleen, and submandibular LN weights in CPA control mice compared with intact vehicle control mice was observed. However, a significant and dose-dependent increase in body, thymus, spleen, and submandibular LN weights were noticed with all three dosages of MHFe as well as with $250 \mathrm{mg} / \mathrm{kg}$ $\beta$-glucan compared with CPA control mice. In addition, $250 \mathrm{mg} / \mathrm{kg}$ MHFe-treated mice showed inhibitory effects on CPA-induced body and decrease in lymphatic organ weight, comparable to treatment with $\beta$-glucan. These findings constitute indirect evidence that MHFe modulated body immune responses. In general, the animals with enhanced immune system have showed relatively good growth patterns [44-46]. In this study, all intact vehicle control mice showed normal body weight increase in same age mice group $[47,48]$.

CPA is a widely used antineoplasic drug, employed alone or in combination with other products [49]. Used as an anticancer drug or in bone marrow transplantation conditioning regimes, CPA severely injures hematopoietic and lymphoid tissues, leading to a profound panleucopenia $[23,24,50]$, with nonregenerative anemia and thrombocytopenia [23-25]. On observing the 13 items of hematology in this experiment, a significant decrease in $\mathrm{WBC}, \mathrm{RBC}, \mathrm{Hb}, \mathrm{Hct}$, and PLT without any meaningful change in differential WBC count, as indication of myelosuppressive nonregenerative anemia, panleukopenia, and thrombocytopenia, was also observed in CPA control mice compared with intact vehicle control. However, these myelosuppressive changes in hematology were normalized by treatment with $\beta$-glucan and all three dosages of MHFe. All three dosages of MHFe dose-dependently inhibited CPA-induced myelosuppressive nonregenerative anemia, panleukopenia, and thrombocytopenia, similar to $\beta$ glucan. These results constitute direct evidence that MHFe exhibits favorable and potent immunomodulatory effects through facilitation of myelohematopoiesis or inhibitory effects on CPA-induced myelosuppression.

The cytokine TNF- $\alpha$, produced by various cell types, including splenocytes, was found to be associated with critical events leading to T-lineage commitment and differentiation [51]. TNF- $\alpha$ can enhance the in vivo immune response at doses much lower than those that cause weight loss or tissue toxicity. It enhances proliferation of $\mathrm{B}$ and $\mathrm{T}$ cells and promotes the generation of cytotoxic $\mathrm{T}$ cells. In addition, it enhances IL-2-induced immunoglobulin production and augments IL-2 stimulated natural killer cell activity and monocyte proliferation [52]. IL-1 is another cytokine released by various cell types, such as macrophages, dendritic cells, lymphocytes, endothelial cells, fibroblasts, and keratocytes, and two forms of IL-1, IL- $1 \alpha$, and IL- $1 \beta$. They are both glycoproteins of $17 \mathrm{kDa}$; IL- $1 \beta$ is secreted by cells and IL$1 \alpha$ is membrane-bound. IL-1 is necessary for the successful initiation of some forms of immune response [53]. IL-10 is an immunosuppressive glycoprotein of $19-21 \mathrm{kDa}$ secreted by Th2 cells, certain B cells, and activated macrophages. It is now clear that IL-10 primarily acts on activated macrophages to suppress their secretion of IL-1, IL-12, TNF- $\alpha$, and reactive oxygen radicals [52]. IFN $-\gamma$ is a glycoprotein of $20-25 \mathrm{kDa}$ produced by CD $8+\mathrm{T}$ cells, Th1 cells, and NK cells in response to IL-2. It has a complex effect on $\mathrm{B}$ and $\mathrm{T}$ cell functions and enhances the NK cell and macrophage activities [52]. CPA depletes the immune $\mathrm{T}$ cells and reduces cytokine release in 
various immune cells $[25,43,54]$. A marked decrease in stimulatory cytokines, splenic TNF- $\alpha$, IL- $1 \beta$, and IL-10 content, and blood IFN- $\gamma$ levels may be due to decline in circulating immune cells after CPA treatment. However, a significant increase in splenic TNF- $\alpha$, IL- $1 \beta$, and IL-10 was observed with all dosages of test substance administered, including the lowest dosage of $125 \mathrm{mg} / \mathrm{kg} \mathrm{MHFe}$, which suggested the potent immunomodulatory effect of $\mathrm{MHFe}$ compared with $\beta$-glucan.

Under CPA-induced myelosuppression, marked functional disorders of various immune cells, including NK cells, have been observed [55-57]. The activation of these immune cells was highlighted as a new treatment regimen for cancer [58-60]. In this study, marked decrease in both splenic and peritoneal NK cell activities was also noticed after CPA treatment, but significant dose-dependent increase in splenic and peritoneal NK cell activities was observed in all MHFetreated mice similar to $\beta$-glucan-treated mice. This suggests that the potent immunomodulatory effects of MHFe may be mediated through the activation of NK cells, at least in part.

Histopathologically, atrophic changes related to depletion of lymphoid cells, particularly $\mathrm{T}$ cell subsets, are induced in the thymus, LN, and spleen after treatment with CPA [25, 42], which was also observed in this experiment. Atrophic changes related to decrease in thymic cortex, splenic white pulp, and submandibular LN lymphoid cells were detected in CPA control mice. This was confirmed by histomorphometrical analysis in this study. However, these lymphatic organ-related atrophic changes were significantly and dosedependently inhibited at all dosages of MHFe, comparable to $\beta$-glucan treatment in this experiment. Once again, these findings are direct evidence that MHFe exhibits favorable and potent immunomodulatory effects through facilitation of myelohematopoiesis or inhibitory effects on CPA-induced myelosuppression.

\section{Conclusion}

MHFe significantly inhibited CPA-induced myelosuppression, a direct evidence of immunomodulatory effects through myelohematopoiesis, compared with $\beta$-glucan (reference drug). Therefore, Kuseonwangdogo-based MHFe is a promising novel potent immunomodulatory agent that can be used in the treatment of various immune disorders with less toxicity.

\section{Disclosure}

All authors have contributed significantly and all authors are in agreement with the content of the manuscript and agree to the conditions outlined in the copyright assignment form. In addition, this manuscript was revised by an English-speaking consultant.

\section{Conflicts of Interest}

No competing financial interests exist.

\section{Authors' Contributions}

Joo Wan Kim and Jae-Suk Choi contributed equally. All the listed authors have read and approved the submitted manuscript.

\section{Acknowledgments}

This research was performed with the support of the 2014 Global Competitive Herbal-Bio Industry Development Projects, by Chungbuk Technopark, and Ministry of Trade, Industry, and Energy, Korea.

\section{References}

[1] S. Sierra, F. Lara-Villoslada, M. Olivares, J. Jiménez, J. Boza, and J. Xaus, "Increased immune response in mice consuming rice bran oil," European Journal of Nutrition, vol. 44, no. 8, pp. 509516, 2005.

[2] B. Patwardhan, D. Kalbag, P. S. Patki, and B. A. Nagsampagi, "Search of immunomodulatory agents," Indian Drugs, vol. 28, no. 2, pp. 56-63, 1990.

[3] S. B. Ghatak and S. J. Panchal, "Investigation of the immunomodulatory potential of oryzanol isolated from crude rice bran oil in experimental animal models," Phytotherapy Research, vol. 26, no. 11, pp. 1701-1708, 2012.

[4] S. Mathew and G. Kuttan, "Immunomodulatory and antitumour activities of Tinospora cordifolia," Fitoterapia, vol. 70, no. 1, pp. 35-43, 1999.

[5] R. K. Chandra and S. Kumari, "Nutrition and immunity: an overview," Journal of Nutrition, vol. 124, no. 8, pp. 1433S-1435S, 1994.

[6] B. P. Chew and J. S. Park, "Carotenoid Action on the Immune Response," Journal of Nutrition, vol. 134, no. 1, pp. 257S-261S, 2004.

[7] K. L. Erickson, E. A. Medina, and N. E. Hubbard, "Micronutrients and innate immunity," The Journal of Infectious Diseases, vol. 182, no. 3, pp. S5-S10, 2000.

[8] M. P. Vinardell and M. Mitjans, "Immunomodulatory effects of polyphenols," Electronic Journal of Environmental, Agricultural and Food Chemistry, vol. 7, no. 8, pp. 3356-3362, 2008.

[9] M. H. Yu, H. G. Im, H. J. Lee, Y. J. Ji, and I. S. Lee, "Components and their antioxidative activities of methanol extracts from sarcocarp and seed of Zizyphus jujubavar. inermis Rehder," Korean Journal of Food Science and Technology, vol. 38, no. 1, pp. 128-134, 2006.

[10] Y.-A. Ham, H.-J. Choi, S.-H. Kim, M.-J. Chung, and S.-S. Ham, "Antimutagenic and antitumor effects of Adenophora triphylla extracts," Journal of the Korean Society of Food Science and Nutrition, vol. 38, no. 1, pp. 25-31, 2009.

[11] S. S. Heroor, A. K. Beknal, and N. Mahurkar, "Immunomodulatory activity of methanolic extracts of fruits and bark of Ficus glomerata Roxb. in mice and on human neutrophils," Indian Journal of Pharmacology, vol. 45, no. 2, pp. 130-135, 2013.

[12] D. Acharya and A. Shrivastava, Indigenous Herbal Medicines: Tribal Formulations and Traditional Herbal Practices, Aavishkar Publishers, Jaipur, India, 2008.

[13] D. Kajaria, J. Tripathi, S. Tiwari, and B. Pandey, "Immunomodulatory effect of ethanolic extract of Shirishadi compound," $A Y U$ (An International Quarterly Journal of Research in Ayurveda), vol. 34, no. 3, pp. 322-326, 2013. 
[14] Y. S. Ju, Y. H. Choi, H. K. Kim, and B. S. Ko, "Effects of Kuseonwangdogo on the proliferation of preadipocyte 3T3-L1 cells, the anti-complementary and cytotoxic effects," Korean Journal of Oriental Medicine, vol. 20, no. 3, pp. 105-114, 1999.

[15] D. J. Jung, B. S. Ko, H. H. Lee, H. S. Choi, and K. J. Park, “Antiviral activity of Korean traditional prescriptions against influenza virus type A," Journal of the Korean Society of Virology, vol. 26, no. 2, pp. 273-283, 1996.

[16] C.-P. Liu, W.-J. Tsai, C.-C. Shen et al., "Inhibition of (S)armepavine from Nelumbo nucifera on autoimmune disease of MRL/MpJ-lpr/lpr mice," European Journal of Pharmacology, vol. 531, no. 1-3, pp. 270-279, 2006.

[17] E. M. Choi, S. J. Koo, and J.-K. Hwang, "Immune cell stimulating activity of mucopolysaccharide isolated from yam (Dioscorea batatas)," Journal of Ethnopharmacology, vol. 91, no. 1, pp. 1-6, 2004.

[18] T.-R. Jang, M.-F. Kao, C.-H. Chen, K.-C. Hsieh, W.-Y. Lai, and Y.-Y. Chen, "Alleviating effects of dehydration under no hyperthermia on the immunomodulatory response to the polysaccharide fraction from fu-ling (Poria cocos) in male collegiate wrestlers," Chinese Medical Journal, vol. 124, no. 4, pp. 530-536, 2011.

[19] X. Huang, J. Qin, and S. Lu, "Kanglaite stimulates anticancer immune responses and inhibits HepG2 cell transplantationinduced tumor growth," Molecular Medicine Reports, vol. 10, no. 4, pp. 2153-2159, 2014.

[20] W. K. Chan, H. K. W. Law, Z.-B. Lin, Y. L. Lau, and G. C.-F. Chan, "Response of human dendritic cells to different immunomodulatory polysaccharides derived from mushroom and barley," International Immunology, vol. 19, no. 7, pp. 891-899, 2007.

[21] V. Maheshu, D. T. Priyadarsini, and J. M. Sasikumar, "Effects of processing conditions on the stability of polyphenolic contents and antioxidant capacity of Dolichos lablab L.," Journal of Food Science and Technology, vol. 50, no. 4, pp. 731-738, 2013.

[22] C. Wu, X. Wang, H. Wang et al., "Extraction optimization, isolation, preliminary structural characterization and antioxidant activities of the cell wall polysaccharides in the petioles and pedicels of Chinese herbal medicine Qian (Euryale ferox Salisb.)," International Journal of Biological Macromolecules, vol. 64, pp. 458-467, 2014.

[23] S. J. Hosseinimehr and M. Karami, "Citrus extract modulates genotoxicity induced by cyclophosphamide in mice bone marrow cells," Journal of Pharmacy and Pharmacology, vol. 57, no. 4, pp. 505-509, 2005.

[24] Q. Hu, J. Xu, and L. Chen, "Antimutagenicity of seleniumenriched rice on mice exposure to cyclophosphamide and mitomycin C," Cancer Letters, vol. 220, no. 1, pp. 29-35, 2005.

[25] H. S. Yoon, J. W. Kim, H. R. Cho et al., "Immunomodulatory effects of Aureobasidium pullulans SM-2001 exopolymers on the cyclophosphamide-treated mice," Journal of Microbiology and Biotechnology, vol. 20, no. 2, pp. 438-445, 2010.

[26] J. L. Benach, G. S. Habicht, T. W. Holbrook, and J. A. Cook, "Glucan as an adjuvant for a murine Babesia microti immunization trial," Infection and Immunity, vol. 35, no. 3, pp. 947-951, 1982.

[27] A. Estrada, C.-H. Yun, A. Van Kessel, B. Li, S. Hauta, and B. Laarveld, "Immunomodulatory activities of oat $\beta$-glucan in vitro and in vivo," Microbiology and Immunology, vol. 41, no. 12, pp. 991-998, 1997.

[28] J.-N. Lee, D.-Y. Lee, I.-H. Ji et al., "Purification of soluble $\beta$ glucan with immune-enhancing activity from the cell wall of yeast," Bioscience, Biotechnology, and Biochemistry, vol. 65, no. 4, pp. 837-841, 2001.

[29] J. M. Zarling, J. Schlais, L. Eskra, J. J. Greene, P. O. Ts'o, and W. A. Carter, "Augmentation of human natural killer cell activity by polyinosinic acid-polycytidylic acid and its nontoxic mismatched analogues," The Journal of Immunology, vol. 124, no. 4, pp. 1852-1857, 1980.

[30] D. R. Strayer, W. A. Carter, S. D. Mayberry, E. Pequignot, and I. Brodsky, "Low natural cytotoxicity of peripheral blood mononuclear cells in individuals with high familial incidence of cancer," Cancer Research, vol. 44, no. 1, pp. 370-374, 1984.

[31] R. S. Hotchkiss, D. F. Osborne, G. D. Lappas, and I. E. Karl, "Calcium antagonists decrease plasma and tissue concentrations of tumor necrosis factor-alpha, interleukin-1 beta, and interleukin-1 alpha in a mouse model of endotoxin.," Shock (Augusta, Ga.), vol. 3, no. 5, pp. 337-342, 1995.

[32] B. D. Clark, I. Bedrosian, R. Schindler et al., "Detection of interleukin $1 \alpha$ and $1 \beta$ in rabbit tissues during endotoxemia using sensitive radioimmunoassays," Journal of Applied Physiology, vol. 71, no. 6, pp. 2412-2418, 1991.

[33] A. Levene, "Pathological factors influencing excision of tumours in the head and neck. Part I," Clinical Otolaryngology \& Allied Sciences, vol. 6, no. 2, pp. 145-151, 1981.

[34] J. Ludbrook, "Update: microcomputer statistics packages. A personal review," Clinical and Experimental Pharmacology and Physiology, vol. 24, no. 3-4, pp. 294-296, 1997.

[35] S. J. Kang, J. E. Lee, E. K. Lee et al., "Fermentation with Aquilariae Lignum enhances the anti-diabetic activity of green tea in type II diabetic db/db mouse," Nutrients, vol. 6, no. 9, pp. 3536-3571, 2014.

[36] P. Promphet, S. Bunarsa, M. Sutheerawattananonda, and D. Kunthalert, "Immune enhancement activities of silk lutein extract from Bombyx mori cocoons," Biological Research, vol. 47, no. 1, pp. 15-24, 2014.

[37] C. Grady, "HIV: Epidemiology, immunopathogenesis, and clinical consequences," Nursing Clinics of North America, vol. 23, no. 4, pp. 683-696, 1988.

[38] M. A. Clark, M. M. Goheen, and C. Cerami, "Influence of host iron status on Plasmodium falciparum infection," Frontiers in Pharmacology, vol. 5, Article ID 00084, 2014.

[39] R. Nicholas, P. Giannetti, A. Alsanousi, T. Friede, and P. A. Muraro, "Development of oral immunomodulatory agents in the management of multiple sclerosis," Drug Design, Development and Therapy, vol. 5, pp. 255-274, 2011.

[40] K. M. I. Bashir and J.-S. Choi, "Clinical and physiological perspectives of $\beta$-glucans: The past, present, and future," International Journal of Molecular Sciences, vol. 18, no. 9, article no. 1906, 2017.

[41] A. Niakani, F. Farrokhi, and S. Hasanzadeh, "Decapeptyl ameliorates cyclophosphamide-induced reproductive toxicity in male Balb/C mice: histomorphometric, stereologic and hormonal evidences," Iranian Journal of Reproductive Medicine, vol. 11, no. 10, pp. 791-800, 2013.

[42] L.-N. Liu, F.-H. Wen, C. Miaskowski et al., "Weight change trajectory in women with breast cancer receiving chemotherapy and the effect of different regimens," Journal of Clinical Nursing, vol. 23, no. 19-20, pp. 2757-2768, 2014.

[43] A. Miyauchi, C. Hiramine, S. Tanaka, and K. Hojo, "Differential effects of a single dose of cyclophosphamide on T cell subsets of the thymus and spleen in mice: Flow cytofluorometry analysis," The Tohoku Journal of Experimental Medicine, vol. 162, no. 2, pp. 147-167, 1990. 
[44] C. G. Duarte, G. L. Dos Santos, A. E. C. S. Azzolini, and A. I. De Assis Pandochi, "The effect of the antithyroid drug propylthiouracil on the alternative pathway of complement in rats," International Journal of Immunopharmacology, vol. 22, no. 1, pp. 25-33, 2000.

[45] J. J. Pinzone, M. L. Fox, M. K. Sastry, D. M. Parenti, and G. L. Simon, "Plasma leptin concentration increases early during highly active antiretroviral therapy for acquired immunodeficiency syndrome, independent of body weight," Journal of Endocrinological Investigation, vol. 28, no. 5, pp. 1-3, 2005.

[46] H. S. Lee, K. J. Yang, H. D. Shin et al., "Single oral dose toxicity studies of Polycan, $\beta$-glucan originated from Aureobasidium in mice," Toxicological Research, vol. 21, no. 4, pp. 361-365, 2005.

[47] J. G. Fox, B. J. Cohen, and F. M. Loew, Laboratory Animal Medicine, Academic Press. Inc., Orlando, FL, USA, 1984.

[48] Y. Tajima, Biological Reference Data Book on Experimental Animals, Soft Science Inc., Tokyo, Japan, 1989.

[49] L. B. Grochow, "Covalent-DNA binding drugs," in The Chemotherapy Source Book, M. C. Perry, Ed., pp. 293-316, Williams \& Wilkins, Baltimore, MD, USA, 1996.

[50] I. Angulo, F. Gómez De Las Heras, J. F. García-Bustos, D. Gargallo, M. A. Muñoz-Fernández, and M. Fresno, "Nitric oxide-producing CD11b+Ly-6G(Gr-1)+CD31(ER-MP12)+ cells in the spleen of cyclophosphamide-treated mice: Implications for T-cell responses in immunosuppressed mice," Blood, vol. 95, no. 1, pp. 212-220, 2000.

[51] S. Samira, C. Ferrand, A. Peled et al., "Tumor necrosis factor promotes human T-cell development in nonobese diabetic/severe combined immunodeficient mice," Stem Cells, vol. 22, no. 6, pp. 1085-1100, 2004.

[52] A. Isaacs, "Lymphokines and Cytokines," in Immunology an Introduction, I. R. Tizard, Ed., pp. 155-169, Saunders, Philadelphia, Penn, USA, 1995.

[53] E. R. Unanue, "The Mononuclear-Phagocytic System," in in Immunology An Introduction, I. R. Tizard, Ed., pp. 61-74, Saunders, Saunders, Philadelphia, Penn, USA, 1995.

[54] C. Q. Xun, J. S. Thompson, C. D. Jennings, S. A. Brown, and M. B. Widmer, "Effect of total body irradiation, busulfancyclophosphamide, or cyclophosphamide conditioning on inflammatory cytokine release and development of acute and chronic graft-versus-host disease in $\mathrm{H}$-2-incompatible transplanted SCID mice," Blood, vol. 83, no. 8, pp. 2360-2367, 1994.

[55] X. F. Du, C. Z. Jiang, C. F. Wu, E. K. Won, and S. Y. Choung, "Synergistic immunostimulating activity of pidotimod and red ginseng acidic polysaccharide against cyclophosphamideinduced immunosuppression," Archives of Pharmacal Research, vol. 31, no. 9, pp. 1153-1159, 2008.

[56] C.-W. Cho, C.-J. Han, Y. K. Rhee et al., "Cheonggukjang polysaccharides enhance immune activities and prevent cyclophosphamide-induced immunosuppression," International Journal of Biological Macromolecules, vol. 72, pp. 519525,2014

[57] J.-Q. Huang, M.-R. Pang, G.-Y. Li, N. Wang, L. Jin, and Y. Zhang, "Alleviation of cyclophosphamide-induced immunosuppression in mice by naturally acetylated hemicellulose from bamboo shavings," Food and Agricultural Immunology, vol. 28, no. 2, pp. 328-342, 2017.

[58] E. S. Ha, S. H. Hwang, and K.-S. Shin, "Anti-metastatic activity of glycoprotein fractionated from Acanthopanax senticosus, involvement of NK-cell and macrophage activation," Archives of Pharmacal Research, vol. 27, no. 2, pp. 217-224, 2004.
[59] G. M. Yu and I. G. Hwang, "In vitro effect of Yuza (Citrus junos SIEB ex TANAKA) extracts on proliferation of human prostate cancer cells and antioxidant activity," Korean Journal of Food Science and Technology, vol. 36, no. 2, pp. 339-344, 2004.

[60] S. Bhattacharya, N. Muhammad, R. Steele, J. Kornbluth, and R. B. Ray, "Bitter melon enhances natural killer-mediated toxicity against head and neck cancer cells," Cancer Prevention Research, vol. 10, no. 6, pp. 337-343, 2017. 


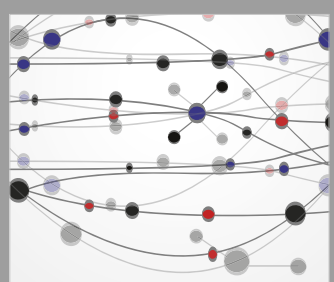

The Scientific World Journal
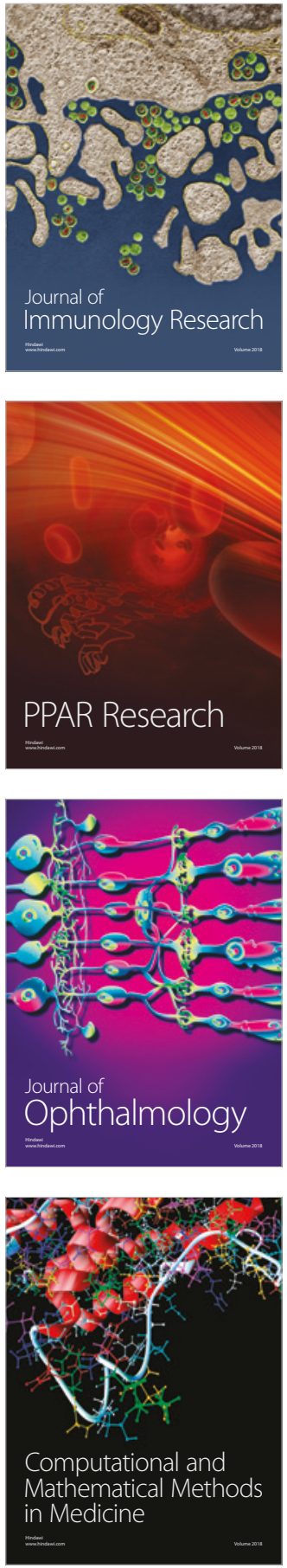

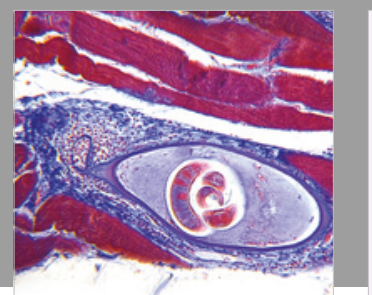

Gastroenterology Research and Practice

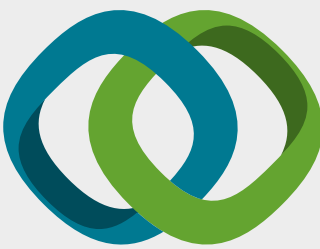

\section{Hindawi}

Submit your manuscripts at

www.hindawi.com
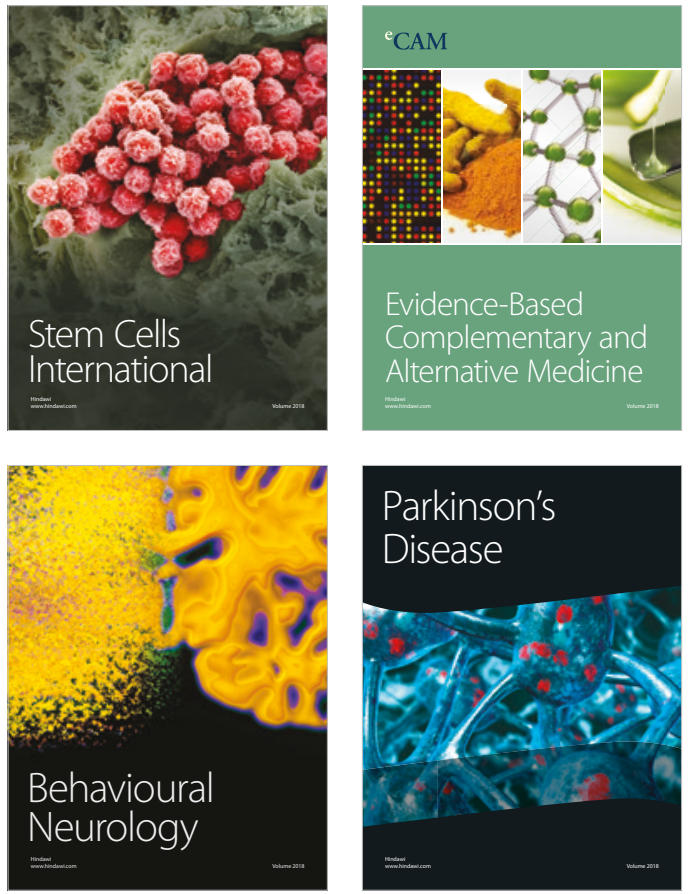

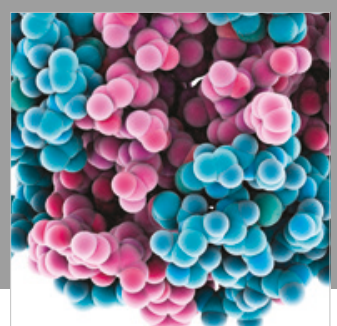

ournal of

Diabetes Research

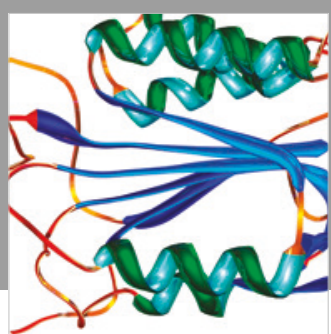

Disease Markers
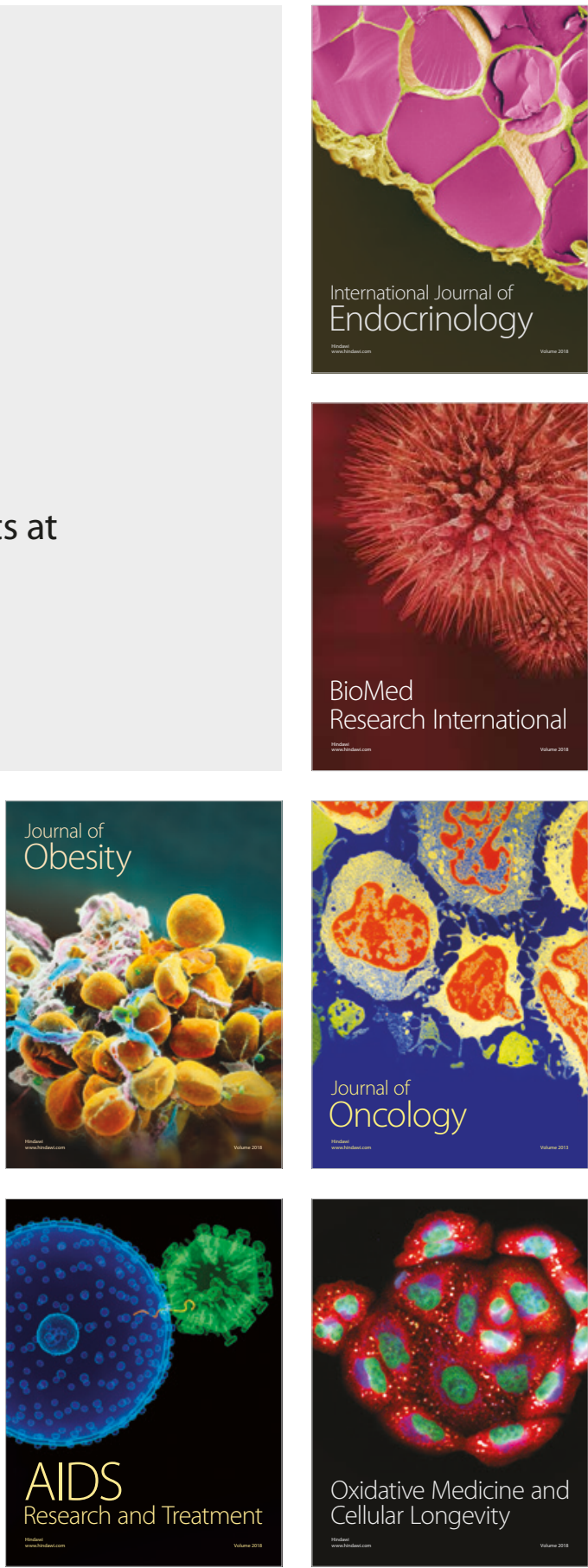